\title{
THE HOLOCENE DEPOSITIONAL HISTORY OF THE IJZER PALAEO- VALLEY (WESTERN BELGIAN COASTAL PLAIN) WITH REFERENCE TO THE FACTORS CONTROLLING THE FORMATION OF INTERCALATED PEAT BEDS
}

\author{
Cecile BAETEMAN
}

(15 figures)

Geological Survey of Belgium, Jennerstraat 13, 1000 Brussels, Belgium

\begin{abstract}
Detailed stratigraphic and sedimentological work, together with radiocarbon datings of the Holocene coastal deposits in the IJzer palaeovalley was performed in order to document the formation of the sedimentary sequence in relation to the controlling factors, to reveal the stratigraphical significance of intercalated peat beds, and to reconstruct the depositional history. Because of the many controversies relating to these topics, the Belgian literature has been reviewed. An initial rapid sea-level rise prior to ca. $7800 \mathrm{cal} \mathrm{BP}$ resulted in a rapid shift of the facies belts across the palaeovalley and was associated with rapid filling with no formation of intercalated peat beds. A deceleration in the rate of the sea-level rise with sufficient sediment supply produced rapid facies changes registered as frequent alternations of mud, peat and gyttja in the sedimentary sequence deposited between ca. 7800 and $6000 \mathrm{cal}$ BP. The facies changes are determined by a sedimentological control related to the tidal channel and creek network, and not by sea-level fluctuations. Periods of peat growth lasted longer and the lateral extension became more widespread as deceleration of the sea-level rise and filling of the plain continued. This was associated with progradation of the shoreface from ca. $6000 \mathrm{cal} \mathrm{BP}$ onwards. Tidal conditions returned to the area from ca. $4000 \mathrm{cal}$ BP onwards. This return was accompanied by erosion and landward migration of the shoreface and channel network. This study demonstrates that the tripartite stratigraphy using Dunkerque and Calais as units should be abandoned in favour of lithological and sedimentological descriptions and age determinations together with environmental interpretation.
\end{abstract}

KEYWORDS: Belgian coastal plain, Holocene, sea-level rise, radiocarbon datings, intercalated peat beds, environmental interpretation.

SAMENVATTING. Een gedetailleerde stratigrafische en sedimentologische studie, ondersteund door ouderdomsbepalingen, werd uitgevoerd in de paleovallei van de IJzer om de vorming van de sedimentaire sequentie in relatie met de oorzakelijke factoren te bepalen en om de stratigrafische betekenis van geïntercaleerde veenlagen te achterhalen. Een reconstructie van de afzettingsgeschiedenis wordt voorgesteld. Vanwege de vele tegenstrijdigheden in de Belgische literatuur wordt er een critisch overzicht van gegeven. De aanvankelijk vlugge zeespiegelrijzing in de periode voor ca. $7800 \mathrm{cal} \mathrm{BP}$ veroorzaakte een vlugge verschuiving van de sedimentaire afzettingsmilieus landinwaarts in de paleovallei samen met een vlugge opvulling, zonder vorming van geïntercaleerde veenlagen. Een vertraging van de snelheid van de zeespiegelstijging en een voldoende sedimentaanvoer veroorzaakten vlugge faciës verschillen die geregistreerd werden als frequente afwisselingen van klei, veen en gyttja in de sedimentaire sequentie afgezet in de periode tussen ca. 7800 en ca. 6000 cal BP. De faciës veranderingen werden veroorzaakt door een sedimentologische factor gecontroleerd door het netwerk van getijdengeulen en kreken, en niet door zeespiegelschommelingen. De perioden van veengroei duurden langer en de laterale uitbreiding van de veengebieden werd uitgestrekter naarmate de snelheid van de zeespiegelstijging verminderde en de opvulling van de vlakte vorderde, wat gepaard ging met progradatie van de kust vanaf ca. $6000 \mathrm{cal}$ BP. Vanaf ca. $4000 \mathrm{cal}$ BP migreert het getijdensysteem en het netwerk van geulen terug landinwaarts.Deze studie heeft angetoond dat de driedelige stratigrafie waarin Calais en Dunkerque als eenheden gebruikt worden, moet verlaten worden ten voordele van lithologische en sedimentologische beschrijvingen ondersteund door ouderdomsbepalingen en interpretatie op basis van sedimentaire afzettingsmilieus.

SLEUTELWOORDEN: Belgische kustvlakte, Holoceen, zeespiegelstijging, radiokoolstof dateringen, verlandingsvenen, sedimentaire afzettingsmilieus. 


\section{Introduction}

Research in the Belgian coastal plain is characterised by a controversy about the formation of the Holocene coastal deposits that has lasted almost 20 years. More specifically, this relates to the link between sea-level rise and coastal sedimentary response, and the stratigraphical significance of peat beds. It is widely believed that the Holocene coastal deposits were formed during two transgressions, i.e. the Calais and Dunkerque transgressions, separated by a one to two metre thick peat layer (called surface peat), with the latter being interpreted as having formed behind a continuous dune belt during a fall in sea level, or according to others, a stable sea level. Although the significance of peat growth in relation to sea-level history was never really investigated in Belgium, this thick single peat layer was accepted as a stratigraphic boundary between the Calais and Dunkerque deposits (transgressions), and a tripartite sub-division was progressively used as a formal lithostratigraphy for the de- posits in the Belgian coastal plain as well as in the legend of the recently published Quaternary Geology map (1/250.000; Maréchal, 1992a).

The objective of this paper is to document the formation of the Holocene coastal deposits in relation to the controlling factors, such as changes in the rate of sealevel rise, sediment supply, accommodation space and palaeomorphology, the effect of the configuration of the tidal flat, and in particular, the effect of the tidal channels on the development of the sedimentary environments and peat growth, and finally, the stratigraphical significance of peat layers in the coastal sequence. Because of the above-mentioned controversy, the existing literature relating to this will be reviewed.

\section{Study area}

The Belgian coastal plain (Fig. 1) is a ca. 15-20 km wide polder area whose elevation varies from +2 to +5

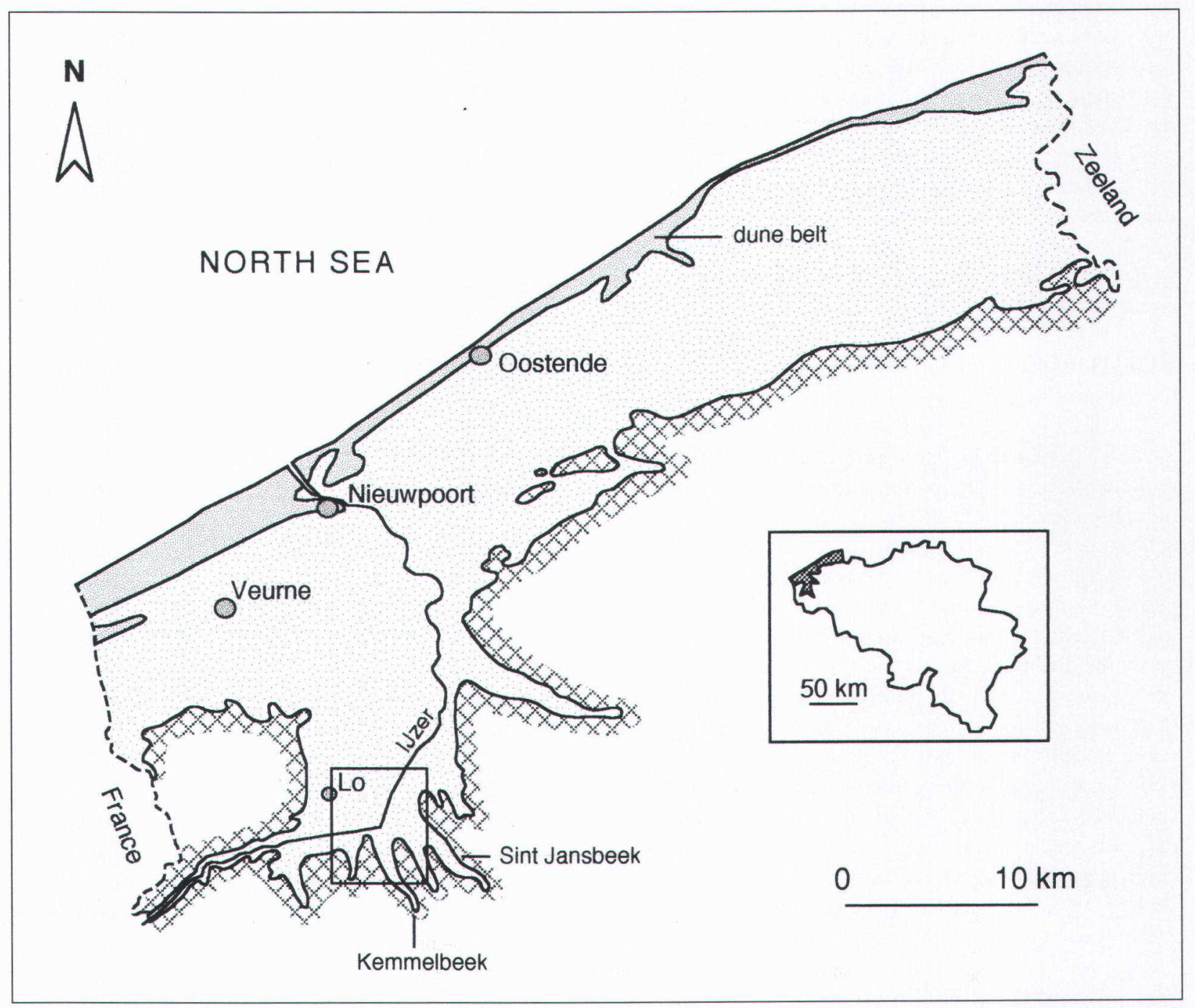

Figure 1. Map of the Belgian coastal plain showing the location of Fig. 7. 
m TAW. The Belgian ordnance datum TAW ("Tweede Algemene Waterpassing") refers to mean low water spring which is about 2 metres below mean sea level. The western part is characterised by a mean tidal range of $4.08 \mathrm{~m}$, and a mean spring tidal range of $4.85 \mathrm{~m}$ (Van Cauwenberghe, 1993). The shoreline is bordered by an almost continuous dune belt. The plain is crossed by a small river, the IJzer which is presently canalized and flows into the North Sea at the town of Nieuwpoort (Fig. 1). The river, together with its two tributaries, the Sint Jansbeek and Kemmelbeek, drains a small and relatively low-lying basin to the south and south-west of the coastal plain.

The Belgian coastal plain is part of the lowlands of the southern North Sea where the Holocene sequence is characterised by an alternation of clastic tidal deposits and peat beds. Because of the presence of a major preHolocene palaeovalley, the western part of the plain (west of Oostende, see Fig. 1) contains the most complete sequence of Holocene deposits, reaching a thickness of about 25 to $30 \mathrm{~m}$ at the coast and narrows to the south where Late-Pleistocene deposits are outcropping.

This paper presents the detailed stratigraphy of the landward portion of the palaeovalley (south of the town of Lo, see Fig. 1) where it is assumed that maximum preservation of the various facies occurs. It is compared with the sedimentary succession in the more seaward areas of the palaeovalley.

\section{Previous work}

The literature relating to Holocene deposits in the Belgian coastal plain adopts two distinct approaches. The first approach is characterised by a description of stratigraphical units called "Calais" and "Dunkerque". The second approach is based on the environmental interpretation and age determination, and describes the development of the coastal plain in relation to sea-level history and sediment supply.

The first (initial) approach was introduced in Belgium by Cornet (1927) by analogy with the work of Dubois (1924) in northern France and worked out by Tavernier $(1938,1943,1946,1947,1948)$ within the framework of the soil mapping survey. The latter work resulted in several papers relating to the content and geographical distribution of the stratigraphic units and some depositional processes (Moormann and Ameryckx, 1950; Moormann, 1951; Maréchal, 1953; Ameryckx, 1959). It should also be noted that the soil maps (and hence the ideas about the coastal evolution) were based on bore holes having a maximum depth of $1.25 \mathrm{~m}$ below the surface. With a few exceptions, later papers are repetitious descriptions (reviewed by Baeteman in
1983). Most of them are marked by a very general lithological description of the units, but lack specific field evidence and dates which could be used as a reference in further research. In addition to the "Soil Survey", Stockmans and Vanhoorne (1954) conducted an extensive botanical study of the surface peat.

According to the above-mentioned papers, the lower part of the Holocene sequence is known as "the Calais unit" which stands for tidal sandy sediments with some clay lenses at the top. It is covered by a 1 to $2 \mathrm{~m}$ thick peat (surface peat) which developed behind a dune belt during a sea-level fall or standstill. The dune belt was breached by a series of new transgressions (Dunkerque units, i.e. two or three distinct phases according to the papers) resulting in the deposition of clay on mudflats and sand in creeks. The latter eroded parts of the peat. A significant compaction of the peat occurred after the area was reclaimed by man.

The evidence for establishing the chronology of the various Dunkerque transgressions was adapted from archaeological research conducted in Zeeland (in the Netherlands) by Tavernier in 1938, and was further documented by regional archaeological features and historical data relating to occupation and dike building (Ameryckx and Verhulst, 1958).

In the course of time, the stratigraphic names, Calais and Dunkerque, have been used in different contexts (e.g. as lithological units, formal lithostratigraphic units, transgressions or phases of inundation). The Dunkerque units are always chronologically defined, i.e. DI: $2^{\text {nd }}$ to $1^{\text {st }}$ century AD, DII: $3^{\text {rd }} / 4^{\text {th }}$ to $8^{\text {th }}$ century AD, DIII: $10^{\text {th }} / 11^{\text {th }}$ to $11^{\text {th }} / 12^{\text {th }}$ century AD. In the Netherlands the dates are different: DI: $500-200$ BC; DII: 250-600 AD; DIII: 800 and later (Zagwijn and Van Staalduinen, 1975).

Processes of infill were not taken into account, except for the phenomenon of relief inversion due to peat compaction. The concept of sea-level changes was only discussed in a stratigraphical context: Calais and Dunkerque being two major transgressions separated by the surface peat representing a standstill or fall in sea level. In all of the papers, the second phase of the Dunkerque transgression (D-II) was always regarded as being the most important event in the formation and development of the coastal plain. This simple depositional history, forced into a tripartite classification, is considered as being representative of the Holocene setting for the entire coastal plain. It is adopted as generally accepted view in Belgium and strongly defended as such (e.g. by the Sub-commission of Quaternary Lithostratigraphy) for the legend of the Quaternary map of Belgium (1/50.000) that is currently being prepared. 
The second approach to Holocene stratigraphy in the Belgian coastal plain has arisen from a revived geological and archaeological interest in the area since the late seventies, triggered by new techniques such as undisturbed hand-augered coring and deep mechanical coring, radiocarbon dating, and diatom analyses. All of these provided new data and have led to a different approach towards, and new ideas about the Holocene infill of the coastal plain. In these research papers, the main emphasis was placed on sedimentary environmental interpretation and palaeogeography based on sedimentology (Baeteman, 1978a, 1981a, 1985a, 1985b), palynology (De Ceunynck, 1985; Baeteman and Verbruggen, 1979; Baeteman et al., 1981), sea-level reconstruction (Baeteman, 1981a; Mostaert, 1985, 1989; De Moor and Mostaert, 1993), palaeoecological diatom studies (Denys, 1985, 1989), chronology (Baeteman and Van Strydonck, 1989; Baeteman, 1991) and archaeology (Thoen, 1978, 1987). The results of these investigations among others showed that:

- the sedimentary characteristics of the deposits and their succession are more complex than those described in the established stratigraphy;

- the surface peat is only one of many intercalated peat layers which developed whilst sea level was rising;

- the different Dunkerque transgressions as such are non-existent.

The shortcomings of the tripartite stratigraphical classification and the problems concerning its further use to describe the depositional history, as well as its use for mapping purposes, were discussed by (Baeteman, 1981b, 1983, 1987) by analogy with investigations in North Germany (Streif, 1978).

Despite the field evidence supported by more than fifty radiocarbon datings published in the period between 1981 and 1991, recent reference syntheses (Maréchal, 1992a, 1992b; De Moor and Pissart, 1992; Houthuys et al., 1993) and summaries (e.g. Gullentops and Broothaers, 1996) still present the Holocene sequence in the same simplified way as 40 years ago, only describing the established stratigraphy with more emphasis on the stratigraphical subdivision itself than on the sediments and the processes of deposition. These papers do not provide new field evidence, although Houthuys et al. (1993) refer to Köhn (1989) who made a comparative study between Northern Germany and Belgium, using the ${ }^{14} \mathrm{C}$ dates and field evidence from Baeteman and Van Strydonck (1989).

Depositional processes and sea-level history are hardly considered, except for vague statements such as "the available evidence clearly shows the triggering function of the sea-level rise, especially for the Atlantic Calais transgressions" (Houthuys et al., 1993). In the latter, the formation of the surface peat is explained by a decreased marine effect, and at the same time as reflecting a rise in the groundwater level induced by a rising sea level. The clastic intercalations in the surface peat "somewhere in the outer reaches of the area", indicate minor transgressions due to changes in the coastal barrier morphology, storm events or brief transgressive episodes.

Depositional processes relating to sea-level rise are mentioned by De Moor and Pissart (1992) via a series of schematic cross-sections, which explains the phenomenon of relief inversion due to differential compaction. The series of cross-sections (Fig. 2) illustrates the evolution of sediment succession just before the Dunkerque inundations until the formation of polders by dike building. However, it also illustrates some peculiarities in sea-level history, since a sea-level rise of more than $5 \mathrm{~m}$ is suggested for the Late Holocene. Datings are not provided, but mean sea level (MSL), high-water (SHW) and low-water (SLW) level at spring tide are indicated, together with a vertical scale. Thus, one can easily calculate that, just before the inundations, the base of the ca. $5 \mathrm{~m}$ thick peat was $2 \mathrm{~m}$ above MSL, and the top was about $7.5 \mathrm{~m}$ above MSL (Fig. 2a). This is far too high for a coastal peat swamp which depends on the groundwater level. Moreover, such a high position would raise the surface of the plain to an elevation of about $+10 \mathrm{~m}$ which, after taking later compaction into account, is too high since today it barely exceeds $+4 \mathrm{~m}$. When the flooding first started (Fig. 2b), the MSL suddenly rose by more than $4 \mathrm{~m}$ and the surface level returned to $+4 \mathrm{~m}$ TAW. In the next step (Fig. 2c), the authors refer to a relative sea-level rise with accumulation of sediments. As shown in the illustration, MSL is now close to the top of the peat, SHW rose almost $1 \mathrm{~m}$ and SLW fell by 0.5 $\mathrm{m}$. In the final stage (Fig. 2e), the authors describe compaction of the peat due to dike building and reclamation of the salt marshes. The peat is compacted by $100 \%$, but its base now lies about $1 \mathrm{~m}$ higher than in the previous step.

Ideas about the relationship between the presence of peat beds and the sea-level rise are expressed in the sea-level curve designed by Gullentops and Broothaers (1996), whereby the sea level drops by about 1 m every time an intercalated peat bed occurs. The surface peat corresponds with a world-wide fall in the sea level between 5000 and $3000 \mathrm{BP}$.

The above-mentioned recent syntheses, characterised by generalities and lack of specific field evidence or references, do not add significant new information to the research papers of the 1950 's, and systematically disregard the data and different ideas published since the 1980's. Other examples demonstrating that the classical stratigraphy is accepted without any further con- 


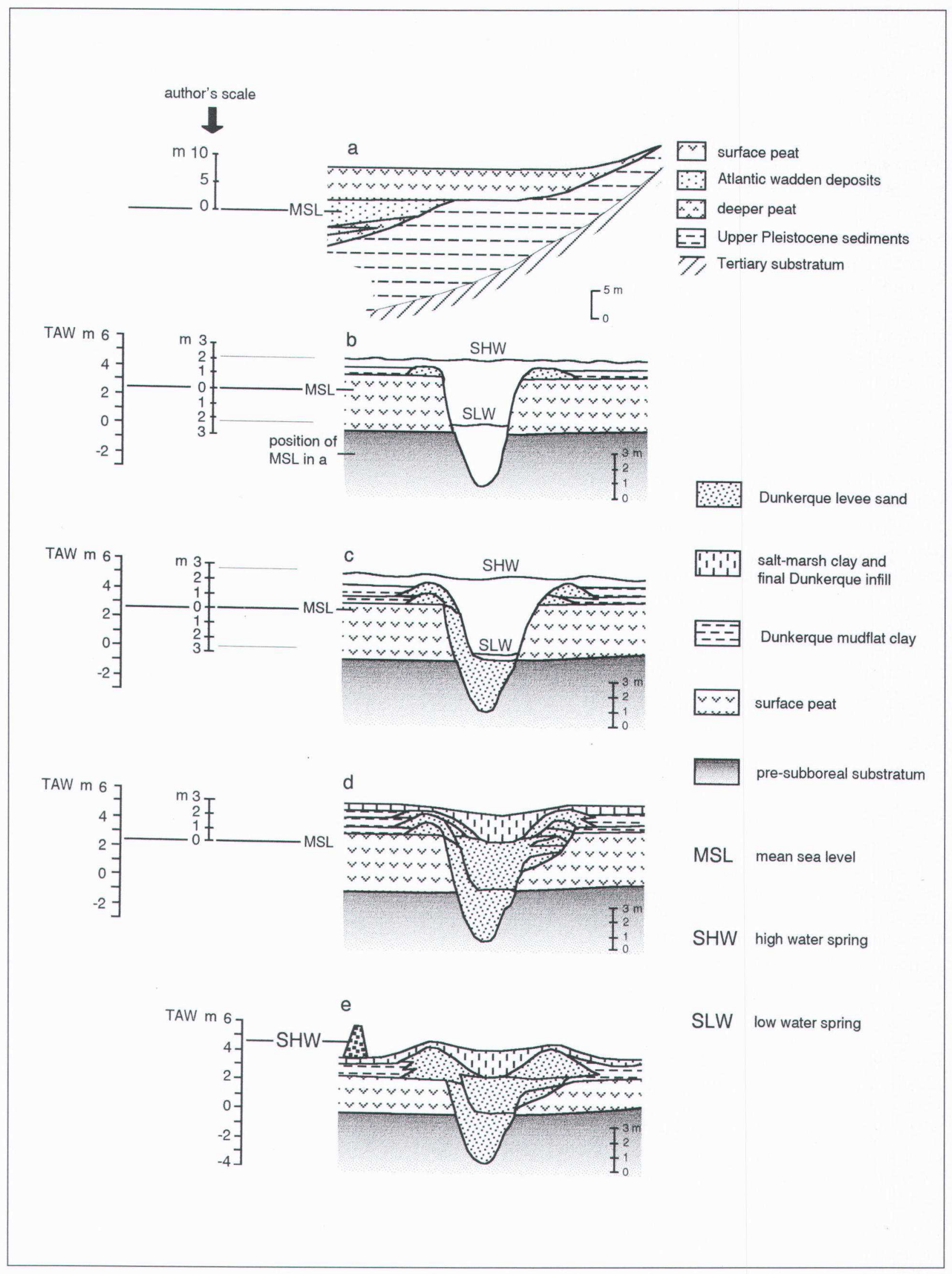

Figure 2. Series of cross-sections explaining the phenomenon of relief inversion due to differential compaction according to De Moor and Pissart (1992). The series illustrates the evolution of sediment succession just before the Dunkerque inundations until reclamation by dike building whereby a sea-level rise of about $5 \mathrm{~m}$ is invoked and compaction of the peat happened after reclamation. 
sideration and consequently leading to aberrant conclusions, are frequently encountered. In a botanical study of the surface peat in the eastern part of the plain, Allemeersch (1991) e.g. states that basal peat is not present. But the major part of the studied peat directly overlies the Pleistocene deposits, however at a much higher level than basal peat should occur according to the classical stratigraphy. Thus, the author did not recognise it as basal peat. Louwye and Declercq (1998) made very detailed altitude measurements of possible sea-level indicators for the reconstruction of water-level positions during the past 2500 years, but adopted the time interval of the Dunkerque-II inundation from the classical literature. This resulted in irrelevant conclusions because this data was never checked and more significantly, it is incorrect (Vos and van Heeringen, 1997, see below).

The most recent research papers relating to the Belgian coastal plain contain a rather extensive overview of the coastal Holocene setting (Baeteman, 1993) and a detailed palaeoecological diatom record of Holocene deposits (Denys, 1993a, 1993b, 1993c) for the western part. A relative mean sea-level curve was constructed by Denys (1993a) and Denys and Baeteman (1995). The chronology of coastal peat formation and the relationship with the rate of sea-level rise was discussed by Baeteman and Denys (1995, 1997). The present paper incorporates a synthesis of these results and original work based on systematic geological mapping.

\section{Database and method}

The database of the western coastal plain consists of more than 1150 undisturbed hand-augered gouge cores, with a large number of them reaching the Holocene/ Pleistocene boundary, and about 100 undisturbed mechanically-drilled cores (labelled with a letter in the text and on the figures) throughout the entire Quaternary sequence. The facies are differentiated on the basis of lithology, sedimentary structures and macro fossils. An isohypse map was constructed (Fig. 3) in order to identify the morphology of the pre-Holocene palaeovalley. Four cross-sections perpendicular to the palaeovalley show the vertical and horizontal facies changes within its fill (Figs. 8, 9, 10 and 11). For the construction of the cross-sections, only those bore holes located on the section were used, i.e. no bore holes have been projected, because of the high variability of the facies. Two longitudinal sections summarize the facies relationships in a seaward direction (Figs. 12 and 13). In the sections, the bore holes are correlated on the basis of sedimentary environmental interpretation. One should bear in mind that additional bore holes can change the interpretation between bore holes that are a large distance apart. The cross-sections are drawn with a substantial vertical exaggeration in order to show the detail.

About 200 radiocarbon datings were obtained from peat and shells and dated at the KIK-IRPA laboratory (Koninklijk Instituut Kunstpatrimonium/Institut Royal Patrimoine Artistique) using the conventional and AMS method referred to as KIK-IRPA (Forest and Van Strydonck, 1993) and UtC (R.J. Van de Graaff Laboratory, Utrecht University, Van Strydonck and Van der Borg, 1991) respectively. The dates are corrected in accordance with the Stuiver and Pearson (1993), Stuiver and Reimer (1993) and Stuiver and Braziunas (1993) calibration taking into account a reservoir age of $400 \pm 40 \mathrm{BP}$ for the shells. In order to simplify matters, the ages are quoted as intercepts and rounded to the nearest 0 or 5 . Details of the radiocarbon datings are published in Baeteman and Van Strydonck (1989), Denys (1993a) and Van Strydonck et al., 1998.

\section{The Pleistocene surface}

The palaeotopography of the Pleistocene deposits (Fig. 3) confirms the existence of a valley running from NW to $\mathrm{SE}$, then turning in a N-S direction in the landward portion where it bifurcates into 3 narrow tributaries. The western tributary follows the course of the presentday IJzer, the two N-S valleys continue as small valleys outside the coastal plain: the Sint Jansbeek and Kemmelbeek (see Fig. 1). Note that the major part of the present-day course of the IJzer is located outside the palaeovalley (Fig. 3).

It is most likely that the valley was formed by river action during the Weichselian sea-level fall and lowstand. The presence of basal peat on top of the Pleistocene deposits, in particular in the deeper parts of the palaeovalley, indicates that the morphology of the valley already existed before the sea level started to rise in the Holocene. This contradicts the current idea in literature where the formation of the valleys is described as a result of erosion in the Boreal period (e.g. Maréchal, 1953). The palaeovalley in fact belongs to a more complex coastal-plain palaeovalley system incised into the Tertiary substratum (Fig. 4), a semiconsolidated clay (Eocene, Formation of Kortrijk, formerly the Ieper Clay). Marine and coastal deposits of the Middle Pleistocene and Last Interglacial highstands have been found in the area (Ponniah, 1977; Baeteman, 1978b, 1981a, 1993) indicating multiple cycles of incision and deposition resulting from fluctuations in base level during the Quaternary. 


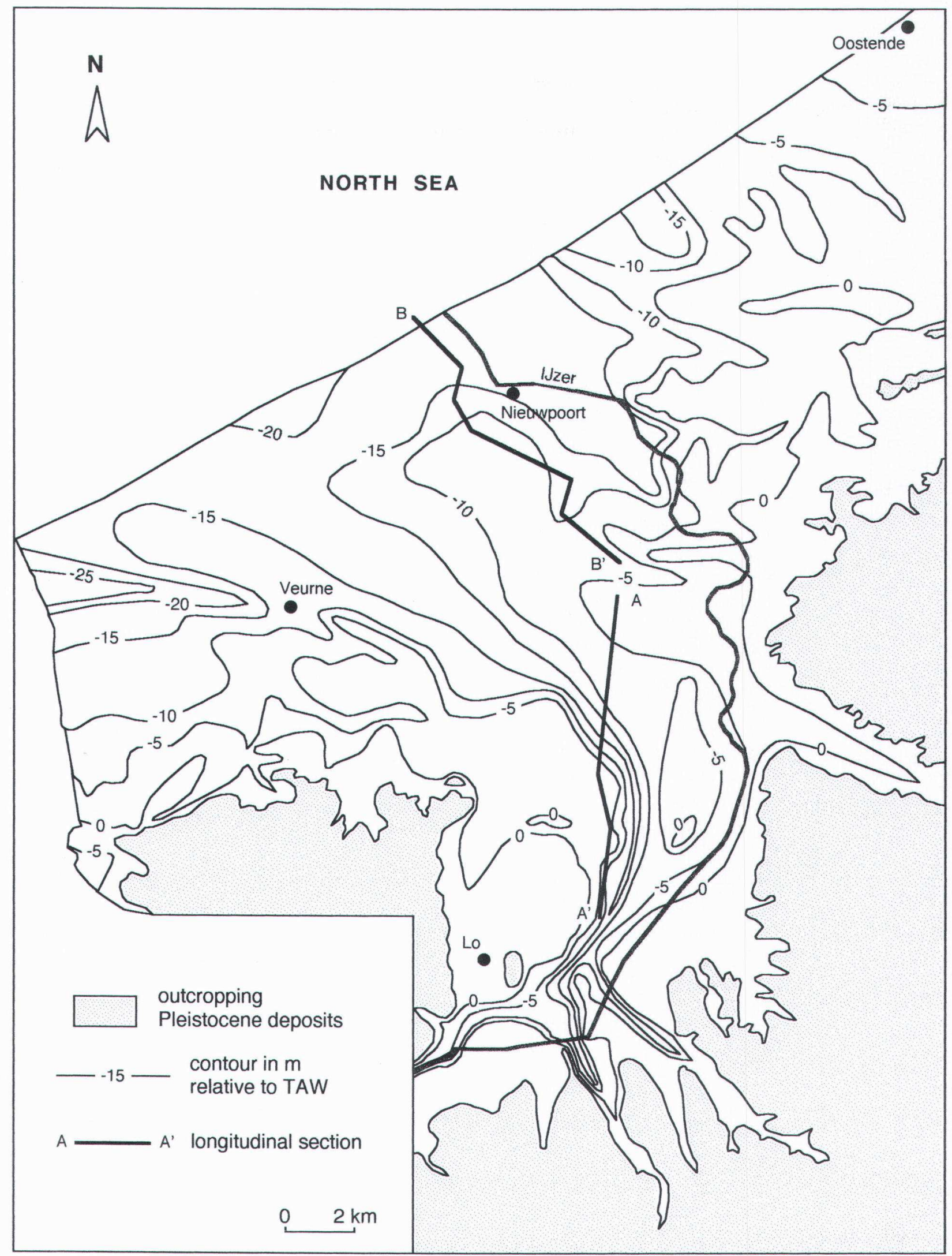

Figure 3. Morphology of the Pleistocene surface showing the presence of a palaeovalley system. The position of longitudinal sections A-A' and B-B' is shown. 


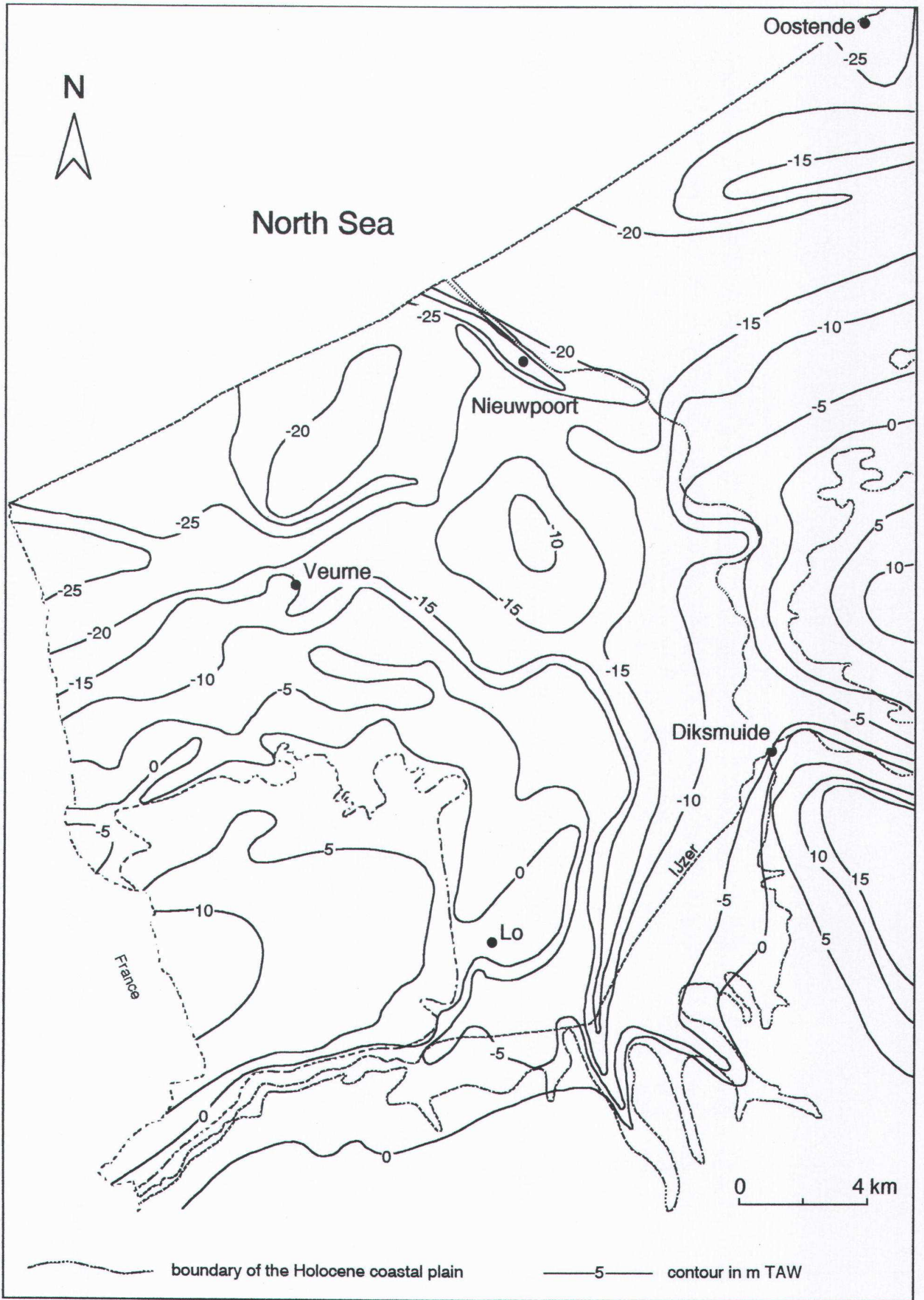

Figure 4. Morphology of the Eocene surface showing the palaeovalley of the IJzer. 
The palaeovalley reaches a depth of about $-14 \mathrm{~m}$ in the landward portion of the plain. In the seaward area, it is almost $-20 \mathrm{~m}$, but there its morphology has been modified by tidal scour during the Holocene transgression. In view of the small amount of discharge from the river and its tributaries, it is most unlikely that, during the Holocene, significant sediment supply originated from the mainland. Besides, Holocene clastic deposits of fluvial origin were not encountered in the infill (Denys, 1993a). Consequently, all sand and mud originated from the sea via tidal currents (Baeteman and Denys, 1997; Baeteman et al., 1999).

\section{Holocene sea-level history and sedimen- tary succession}

The infill of the western coastal plain initiated in the palaeovalley of the river IJzer (Fig. 3). The post-glacial relative sea-level (RSL) rise induced the groundwater level to rise, resulting in the development of freshwater marshes in which peat accumulated. This peat, the basal peat, is a time-transgressive unit shifting landward and upward with the rising sea level. The age and elevation of the basal peat were used to con- struct the relative mean sea-level curve (Denys, 1993a; Denys and Baeteman, 1995). The basal peat forms the base of the coastal Holocene sequence where it was not eroded by tidal scour. The sea invaded the area via the main palaeovalley which changed into an embayment or tidal basin with channels and flats. As the drowned system did not receive sediment from fluvial sources, the term "tidal basin" is preferred, rather than estuary.

The general trend of the sea-level curve (Fig. 5) shows that initially the RSL rise was rapid, rising at an average rate of $7 \mathrm{~m} / \mathrm{ka}$ in the period before ca. $7500 \mathrm{cal} \mathrm{BP}$. This resulted in a rapid landward shift of the tidal environment towards a position close to the present-day boundary of the coastal plain (Fig. 6) (Baeteman and Denys, 1995; 1997; Baeteman et al., 1999). Since no evidence for a lagoonal environment for that period was ever encountered, it is assumed that sediment accumulation kept pace with the rate of sea-level rise.

At ca. 7500-7000 cal BP, the RSL curve shows a distinct retardation to an average of $2.5 \mathrm{~m} / \mathrm{ka}$. Consequently, the rapid landward shift of the tidal environment stopped. Moreover, sediment supply now outran

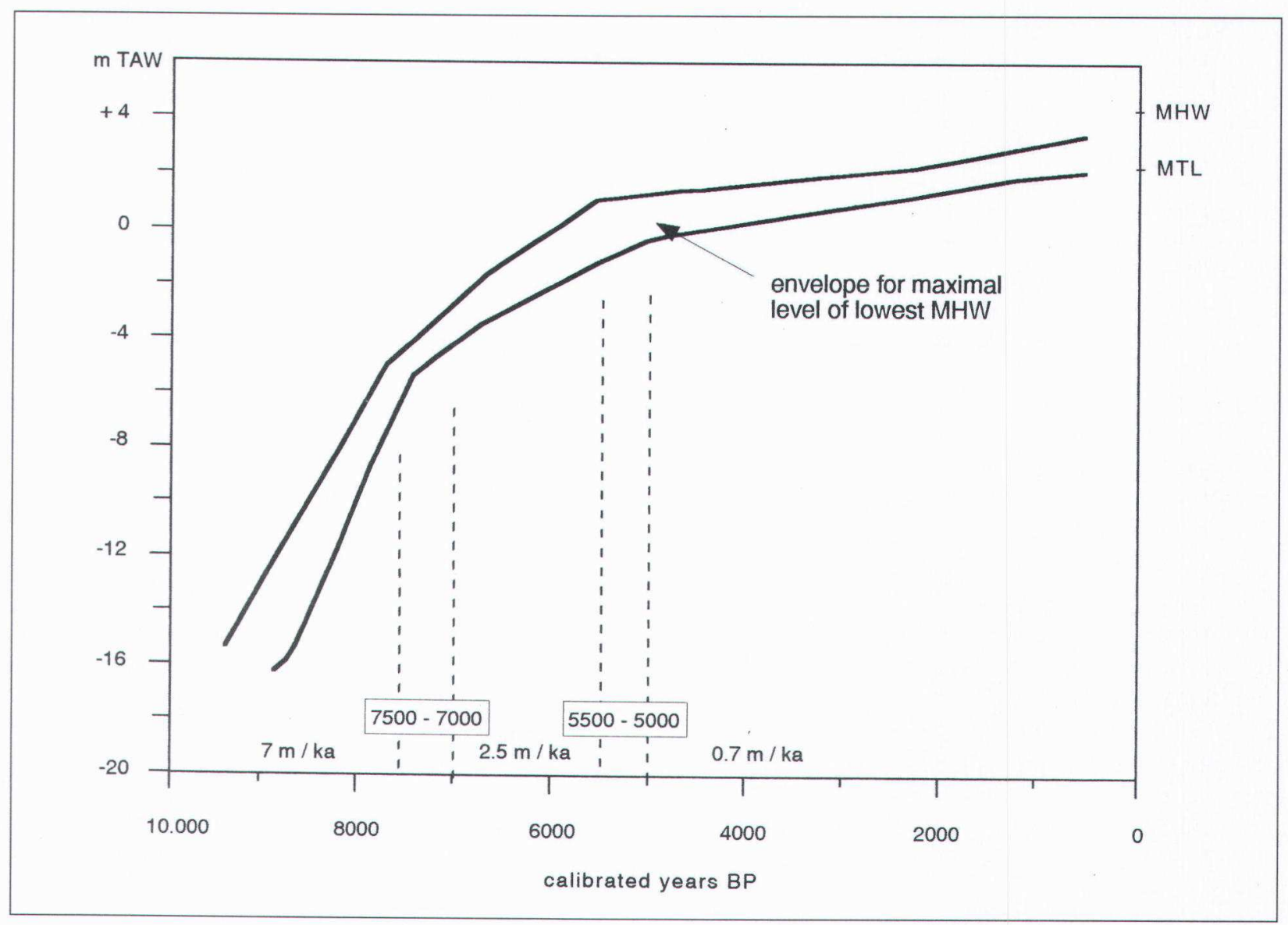

Figure 5. Relative sea-level curve for the study area with indication of the average rate of sea-level rise (after Denys and Baeteman, 1995). 


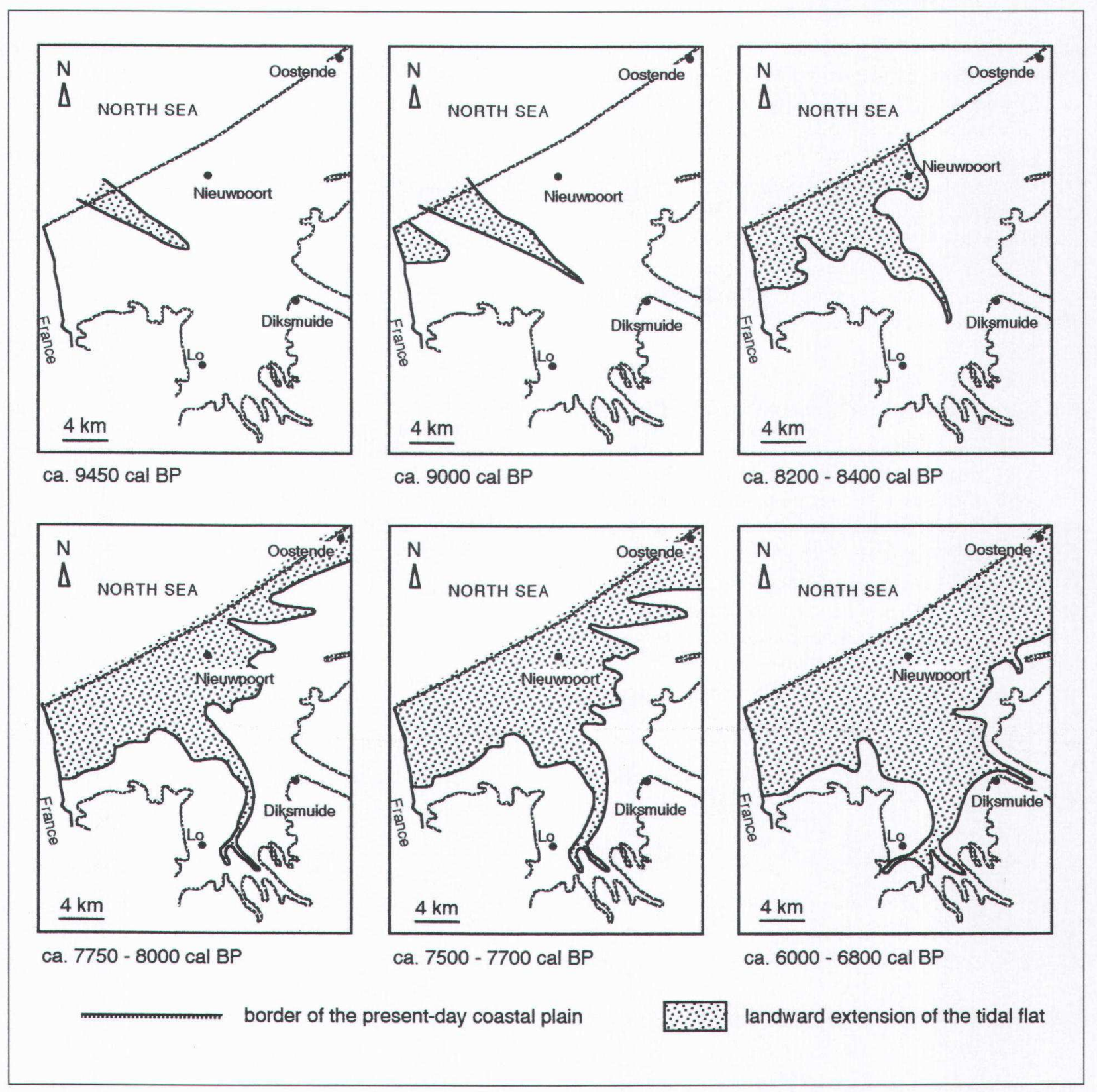

Figure 6. Palaeogeographical maps showing the rapid landward extension of the tidal area since the beginning of the inundation at ca. 9450 cal BP until ca $6000 \mathrm{cal} \mathrm{BP}$. The position of the present-day shoreline is shown for reference.

the accommodation space created by sea-level rise so that the tidal basin was rapidly filled by sediment. Peat started to develop, initially short-lived and local, showing no regular pattern in the distribution (Baeteman and Denys, 1995; 1997). However, by ca. $6800 \mathrm{cal} \mathrm{BP,}$ peat had accumulated on a more regional scale. As a result of the decrease in the rate of sea-level rise, the sequence deposited in the period between ca. 7800 and ca. 5500 cal BP consists of peat beds alternating with tidal flat deposits. The rate of relative sea-level rise continued to decrease, and after ca. 5500-5000 cal BP, it fell to an average of $0.70 \mathrm{~m} / \mathrm{ka}$ (Fig. 5). This period corresponds well with the development of the thickest intercalated peat layer, although the initiation of it dates back to as early as ca. $6200 \mathrm{cal}$ BP in certain areas (Baeteman and Denys, 1997). The flooding of this peat started as early as ca. $4450 \mathrm{cal}$ BP, but in the landward part of the plain, peat accumulation lasted until about 1500 cal BP (Baeteman, 1991). A more precise time limit for the end of the peat accumulation cannot be given because of the wide range of dates for its termination which is not necessarily coeval with the onset of the renewed tidal flooding (see Denys, 1999). The peat is covered by a 1 to $2 \mathrm{~m}$ thick tidal flat deposit which forms the final fill of the plain. 
According to the old stratigraphic scheme discussed above, the deposits below the thickest intercalated peat layer are called "Calais"; those above this layer are called "Dunkerque". This stratigraphy does not take account of the alternation of clay and peat beds. However, the latter is one of the most typical characteristics of the sedimentary succession.

\section{Stratigraphy of the palaeo-valley fill}

A simplified profile type map (Fig. 7) constructed on the basis of a dense boring grid shows the 3 tributaries of the main palaeovalley in the southern part of the plain. The Holocene sequence can be summarised by means of two completely different sedimentary successions, represented as two profile types. The initial fill that mainly consists of alternating mud and peat is called the palaeovalley fill. The second profile type represents a sand-filled tidal channel that eroded the palaeovalley fills to a great extent except for the
Kemmelbeek palaeovalley. The restricted areas where the tidal channel only eroded the upper part of the palaeovalley fill are not indicated on the map.

\subsection{Cross-section 1}

The southernmost cross-section (Fig. 8) shows two palaeovalleys from which the complete sequence of infill was encountered in only one bore hole for each valley. The two palaeovalleys have a different fill. The Kemmelbeek palaeovalley with bore hole Wh is about $250 \mathrm{~m}$ wide and $14 \mathrm{~m}$ deep; the Sint Jansbeek palaeovalley with bore hole $3-\mathrm{Gr}$ is about $150 \mathrm{~m}$ wide and $10 \mathrm{~m}$ deep. Detailed palaeoecological diatom studies were carried out by Denys (1993a) on both cores.

In the Kemmelbeek palaeovalley (bore hole Wh), the Eocene clay is overlain by a ca. $1 \mathrm{~m}$ thick layer of clay with irregular sand laminae, peat fragments and pebbles of Eocene clay. This basal layer is covered by al-

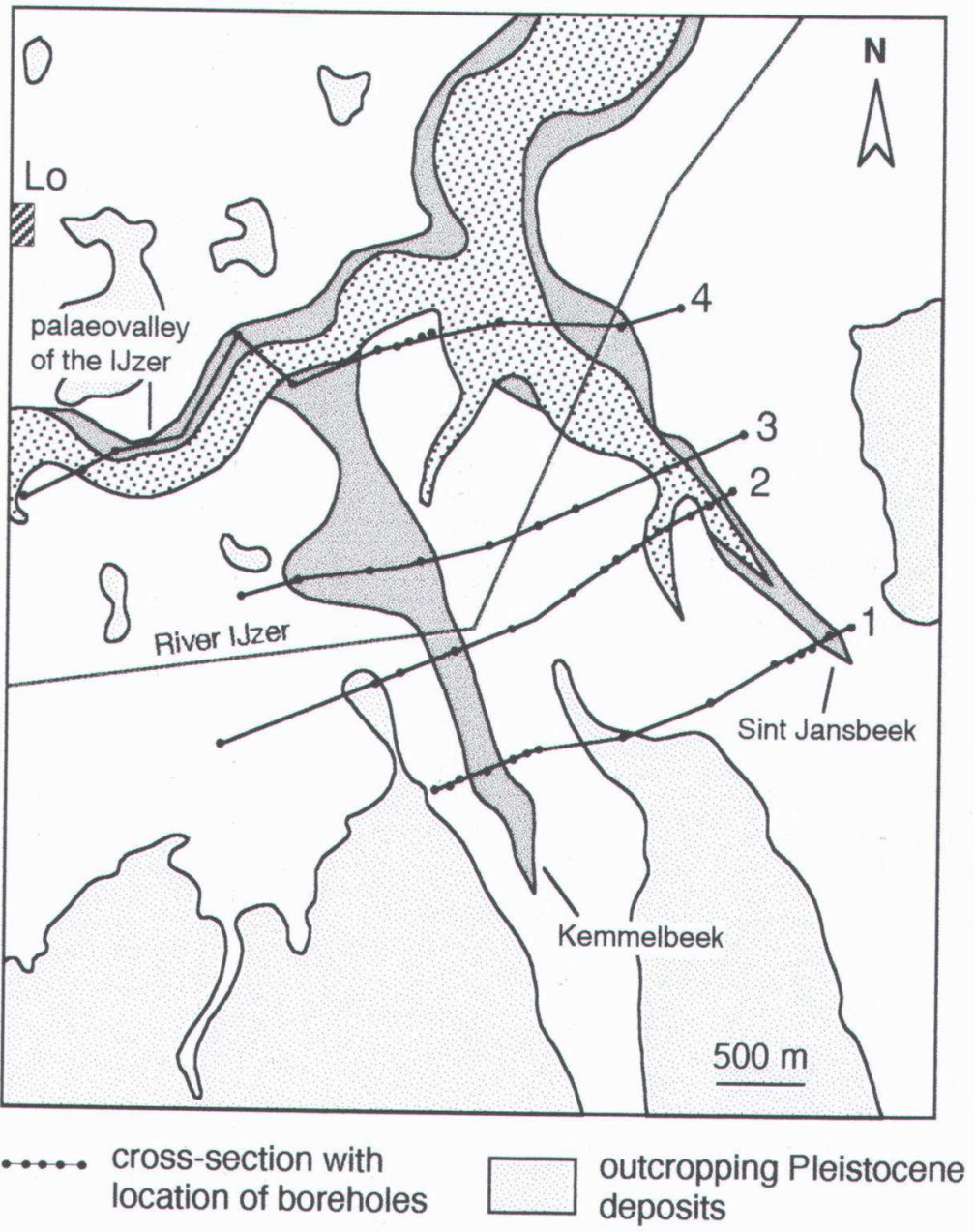

\section{Explanation of Profile Types}

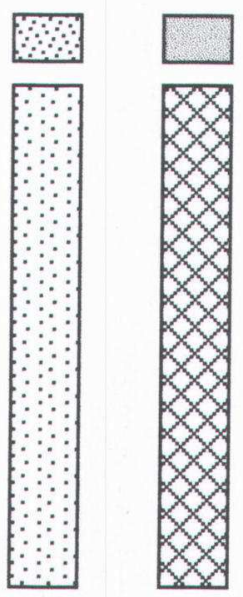

\section{Legend of Profile Types}

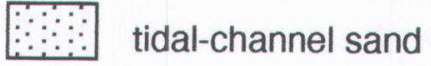

palaeovalley fill

Figure 7. Simplified profile type map of the Holocene sequence in the three tributaries in the landward part of the plain with indication of the cross-sections. Location of the map is shown in Fig. 1. 


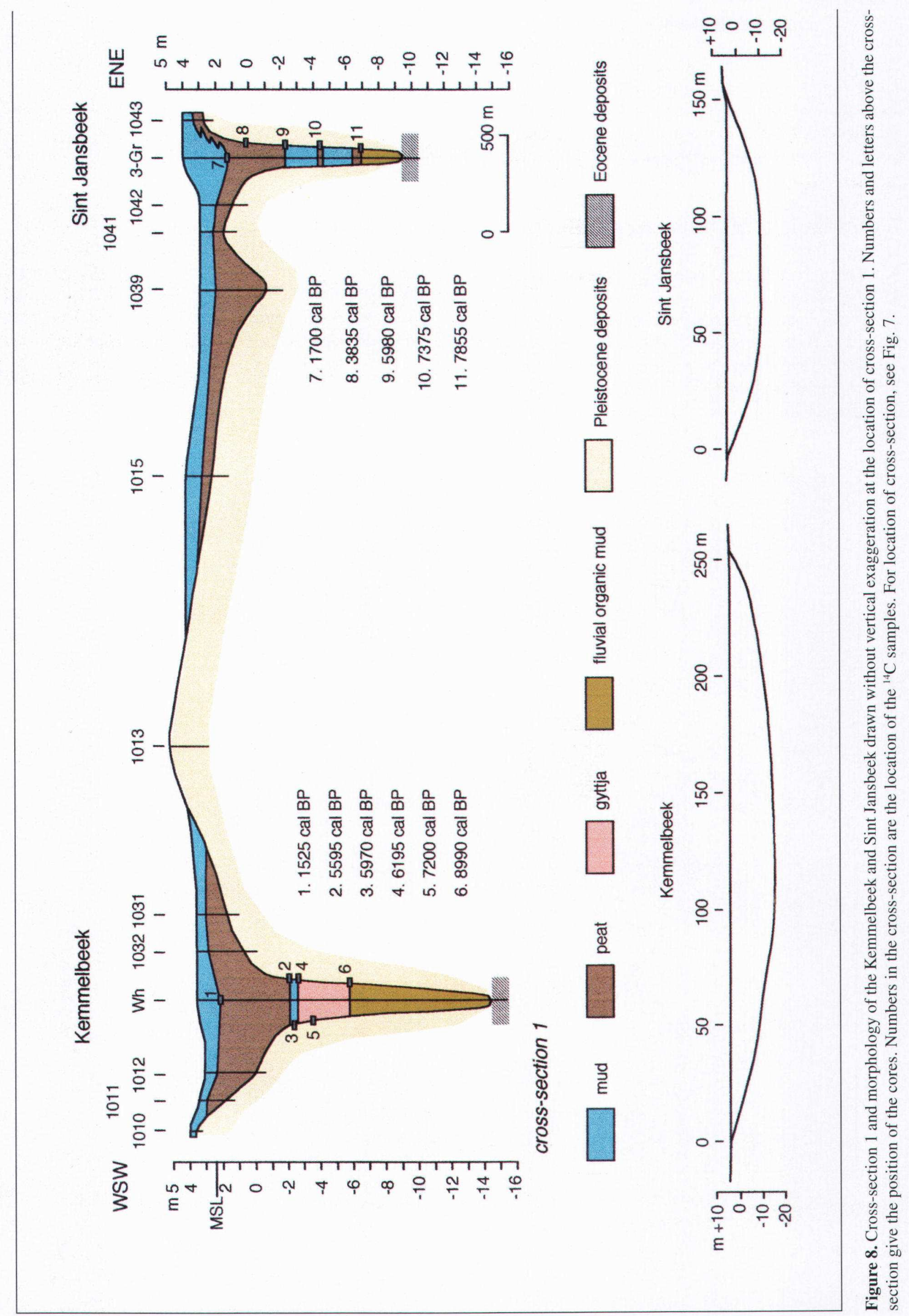


most 8 metres of a strongly decomposed, amorphous heterogeneous mixture of organic matter and mud containing abundant fragments of wood. Such a deposit can be a channel fill in an abandoned channel or occur over areas of deeply flooded river bottom swampland (Stone and Gleason, 1981). According to the pollen content and macro remains (e.g. nuts of Corylus avellana), both deposits most probably date from the early Holocene (Verbruggen, unpublished; futher research is in progress) implying that Pleistocene deposits are absent, and the Holocene deposits are directly overlying the Eocene clay without any fluvial sands or gravels.

The mixture of organic matter and mud is overlain by an almost $3 \mathrm{~m}$ thick gyttja, the base of which is dated at ca. $8990 \mathrm{cal} \mathrm{BP}$. Few thin laminae of very fine inorganic sediment are intercalated in the gyttja, most probably originating from freshwater floodings since no signs of tidal effects are apparent. The top of one was dated at ca. $7200 \mathrm{cal} \mathrm{BP}$. The first tidal effect recorded in mudflat clay is dated at ca. $6195 \mathrm{cal} \mathrm{BP}$. The maximum tidal effect (Denys, 1993a) is dated at ca. 5970. At ca. $5595 \mathrm{cal}$ BP, the tidal flat environment changed into a freshwater marsh and about $4 \mathrm{~m}$ of peat accumulated continuously until ca. 1525 cal BP without any further tidal effect according to the diatoms. The peat growth is halted by renewed flooding (Denys, 1993c) resulting in the eventual development of a mudflat evolving into a salt marsh representing the final stage of this palaeovalley fill.

In the Sint Jansbeek palaeovalley (bore hole 3-Gr), the Eocene clay is overlain by $2 \mathrm{~m}$ of silty clay showing root penetration. It contains plant remnants and numerous spots of vivianite, the latter indicating a reduced environment rich in organic matter. However, the lowermost part also exhibits oxidised zones and includes large Eocene clay fragments, denoting a reworking of the Eocene deposits in a fluvial environment. Whether this happened during the Pleistocene or Holocene is not known. It certainly happened before the area was affected by the RSL rise, because it is covered by a peat layer that developed due to the local rise in the groundwater table (Denys, 1993a). The base of the peat is dated at ca. $7855 \mathrm{cal} \mathrm{BP}$. It is overlain by an almost $2 \mathrm{~m}$ thick sequence of intertidal flat deposits. The lower part of this sequence is characterised by a rapid alternation of highly bioturbated sediments (with numerous articulated Scrobicularia plana in situ) with thinly laminated sand and mud denoting alternating periods of low deposition and current activity. Several advanced silting-up phases with intense reed penetration were found in the upper part, with the latter resulting in the formation of fen peat at ca. $7375 \mathrm{cal} \mathrm{BP}$ (found at ca. $-4 \mathrm{~m}$ ). This intercalated peat bed is one of the oldest known in the entire coastal plain. The $2 \mathrm{~m}$ of clay and silt, deposited within a timespan of about 500 years, implies that sufficient sediment was provided and that accretion could keep pace with the rapid sea-level rise. In the overlying $2 \mathrm{~m}$ of mudflat deposits, evidence of current activity is not apparent; on the other hand, some levels with intense reed growth can be found. This intertidal flat sedimentation was followed by another phase of peat growth that started at ca. 5980 cal BP. Ecological changes in this peat bed (Denys, 1993a) indicate that the freshwater marsh has been affected by brackish water during its accumulation which lasted about 4300 years, denoting the existence of a tidal channel nearby.

The peat growth here came to an end at ca. $1700 \mathrm{cal}$ $\mathrm{BP}$ and changed to a mudflat that accreted for about 3 m. A salt marsh environment was only encountered towards the top (denys, 1993a).

\subsection{Cross-section 2}

The palaeovalley fill of the Sint Jansbeek was not cored in this cross-section (Fig. 9) which is located about $0.7 \mathrm{~km}$ north of cross-section 1 (see Fig. 7). According to the profile-type map, the palaeovalley fill is located between bore holes 1019 and 1029. The gyttja at the base of core 1019 most probably belongs to it. In core 1029 which is at the edge of a channel, the Pleistocene deposits are covered by a $2.5 \mathrm{~m}$ thick deposit consisting of an irregular alternation of horizontally layered mud, sand, peat detritus mixed with sand, and peat fragments. Peat pebbles are present at the erosive base. A similar facies, but with larger reworked fragments of peat and wood, and with slump structures, was found in bore hole $\mathrm{N}$, which is located outside the Sint Jansbeek palaeovalley. These characteristics denote erosion and the formation of new tidal channels scouring the palaeovalley fill. This channel facies should not be interpreted as originating from the channel that initially filled the palaeovalley. At this location, the channels eroded most of the palaeovalley fill and, in view of the large wood fragments, also parts of the basal peat which developed on the higher Pleistocene surface.

The palaeovalley fill of the Kemmelbeek was encountered in only one bore hole (1009) which reached the Pleistocene surface at $-7.65 \mathrm{~m}$. The sequence starts with a slightly organic mud with freshwater gastropods and numerous root penetrations. The mud changes to gyttja which is overlain by a $1 \mathrm{~m}$ thick peat layer at about -4 $\mathrm{m}$. The peat is covered by a thin layer of non-calcareous mud containing numerous reed rhizomes. It is overlain by gyttja and a $2.5 \mathrm{~m}$ layer of thick peat. The oldest tidal sediments recorded in bore hole Wh (see cross-section 1) at a depth of ca. $-2.5 \mathrm{~m}$ and dated at ca. $6195 \mathrm{cal}$ BP was not found in bore hole 1009. Tidal 


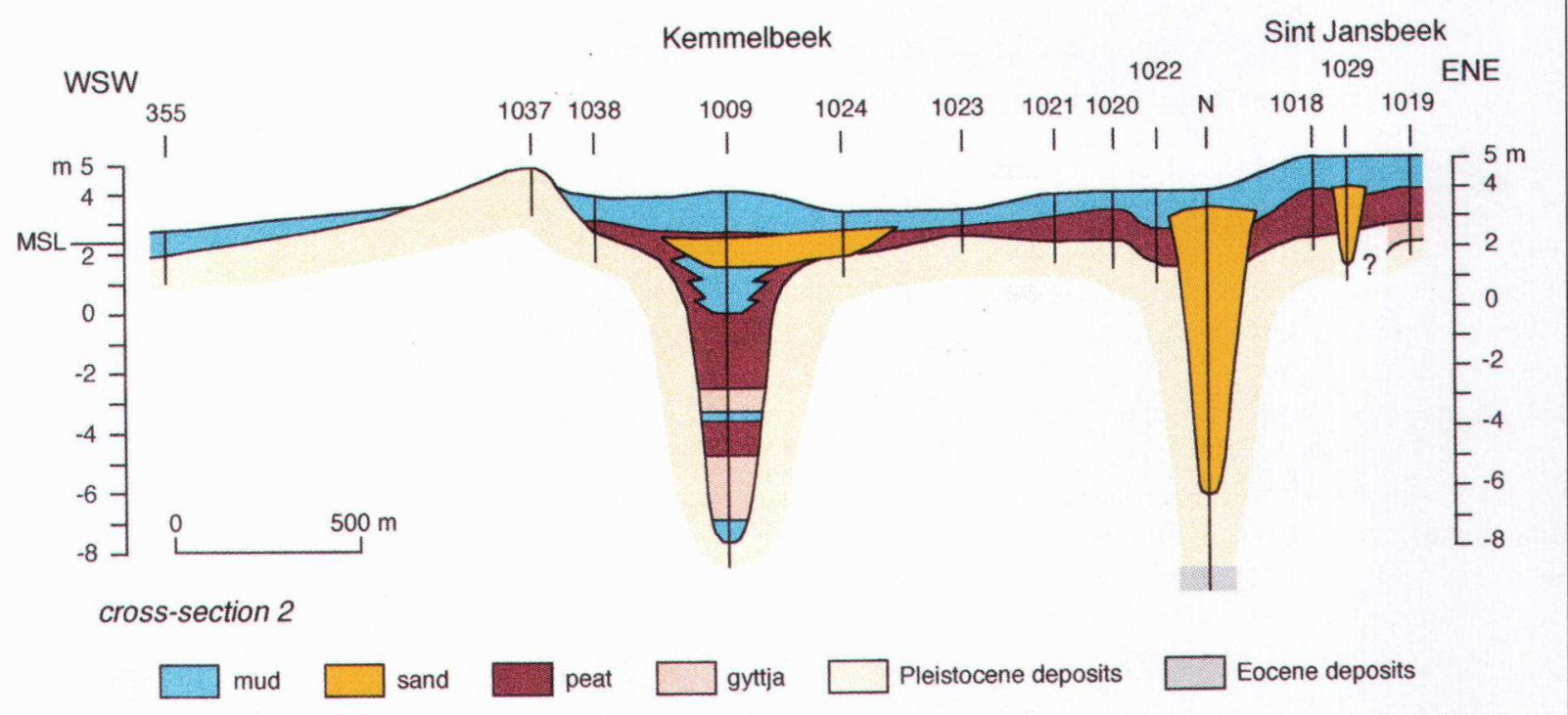

Figure 9. Cross-section 2. For location of cross-section, see Fig. 7.

sediments should be present at that level, because tides reached as far as bore hole Wh. This points to rapid lateral facies changes across the palaeovalley and each bore hole shows a different sediment succession. While peat is growing and gyttja is accumulating at one side of the valley, tidal mud is deposited at the other side. The top of the peat is situated at $0 \mathrm{~m}$, which is about 2 metres lower than in bore hole Wh. It is overlain with an erosional contact by calcareous clay which is slightly peaty and contains numerous reed rhizomes. Reworked peat fragments occur at the very base; the top of the peat layer shows mud-filled cracks. It is clear that the top of the peat was eroded by tidal action. However, the latter was still weak in view of the intense reed growth, but on the other hand, it was providing too much sediment for peat growth to continue. The slightly peaty mud is overlain with an erosional contact by almost half a metre of sand with lumps of peaty clay at the base, denoting erosion, most probably by overbank flooding from a nearby tidal channel. The same facies was found in core 1024. On top of the sand, a $10 \mathrm{~cm}$ thick peat bed occurs with roots penetrating into the sand. This indicates that shortly after the sand deposition, freshwater conditions were re-established and peat accumulated again at this site for a short time until it was eventually covered by mudflat sediments. The sedimentary succession above the thick peat layer with erosion and resumed peat growth, illustrates that the end of the peat growth happened in successive steps.

\subsection{Cross-section 3}

In cross-section 3 (Fig. 10), located about $0.5 \mathrm{~km}$ to the north of cross-section 2, the palaeovalley fill of the Sint Jansbeek was not encountered. Instead, tidal channel facies was found (bore hole 1017), consisting of an alternation of laminated sand and clay with peat detritus. Like in cross-section 2, the major portion of the palaeovalley fill at this location has been eroded by a tidal channel after the palaeovalley was almost completely filled (see Fig. 7).

The Kemmelbeek palaeovalley is about $1 \mathrm{~km}$ wide here. Its fill was encountered in three bore holes. The base of the Holocene sequence was not reached in core 987 at the deepest part of the palaeovalley. Gyttja is found in the lower part (core 987) covered by a thin peat bed at $-8 \mathrm{~m}$ and overlain by a $4 \mathrm{~m}$ thick sequence consisting of an alternation of gyttja with intertidal mud which is characterised by intense reed growth and slightly 


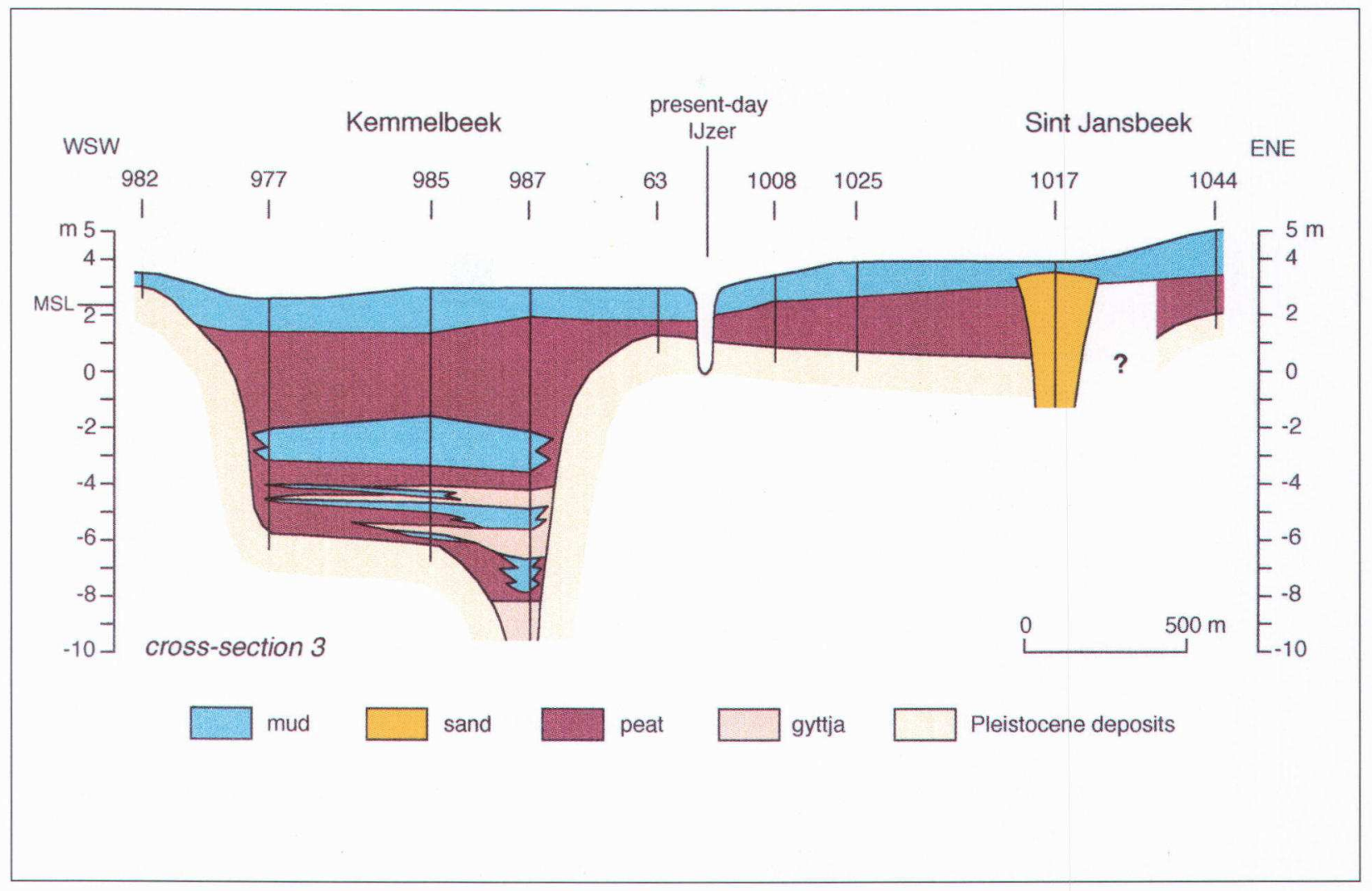

Figure 10. Cross-section 3. For location of cross-section, see Fig. 7.

peaty horizons The palaeovalley widens above $-6 \mathrm{~m}$. Here, the fill shows rapid lateral and vertical facies changes, so that the succession differs in each bore hole. Peat predominates between -6 and $-4 \mathrm{~m}$ in particular along the western margin of the palaeovalley (bore hole 977). Thin intercalations of mud and gyttja occur. Core 985 is characterised by the rapid alternation of peat, gyttja and tidal mud, the latter with numerous Hydrobia sp. Core 987 is dominated by gyttja and mud between -6 and $-4 \mathrm{~m}$. Above $-4 \mathrm{~m}$, the succession in the cores is similar.

In this cross-section, the lower part of the fill of the Kemmelbeek is predominantly characterised by freshwater deposits. From $-7.5 \mathrm{~m}$, the tidal effect is perceptible, and from $-4.5 \mathrm{~m}$, it becomes evident over the entire valley. Above $-4 \mathrm{~m}$, the sediment succession is similar in the three boreholes. The peat is covered by an almost 2 m thick mudflat deposit with abundant Scrobicularia plana and Hydrobia sp. It is overlain by a more than $3 \mathrm{~m}$ thick peat layer which merges with the basal peat covering the Pleistocene deposits outside the palaeovalley.

\subsection{Cross-section 4}

In section 4 (4a and 4b, Fig. 11), located about $1.2 \mathrm{~km}$ to the north of cross-section 3, the palaeovalleys of the Sint Jansbeek, Kemmelbeek and IJzer are crossed (see Fig. 7).

Although the Pleistocene surface was not reached, it is most likely that the sediment succession in bore hole 1027 (cross-section 4a) belongs to the palaeovalley fill of the Sint Jansbeek. Compared with the southern part of the Sint Jansbeek palaeovalley (bore hole 3-Gr, Fig. $8)$, the almost $4 \mathrm{~m}$ thick peat bed occurs at the same level. However, the underlying tidal sediments are more sandy and the peat bed found at $-4 \mathrm{~m}$ is not present here. The younger tidal channel which eroded the major part of this palaeovalley fill and scoured into the Pleistocene deposits was found in bore hole W. The sediments consist of layered mud and sand containing many broken shells, peat fragments and clay pebbles. Towards the base, reworked Pleistocene material is evident. At the contact of the channel deposits and the Pleistocene subsoil, a channel lag contains peat and wood which was dated at ca. $3600 \mathrm{cal} \mathrm{BP}$ indicating that it came from the top of the upper thick peat layer. The top of the peat outside the palaeovalley at $+2 \mathrm{~m}$ 


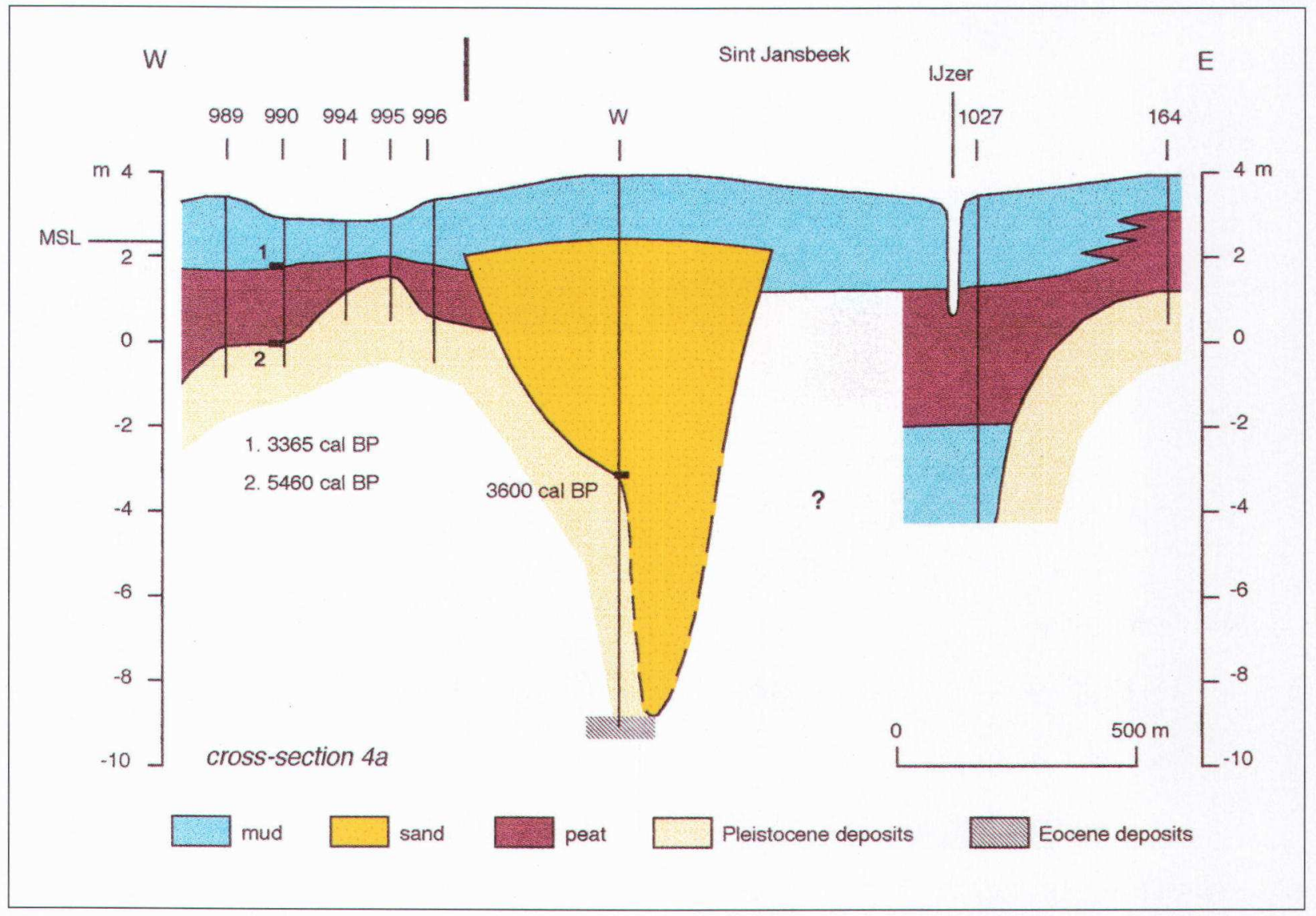

Figure 11a. Cross-section 4a and 4b. For location of cross-section, see Fig. 7.

TAW where no erosion is suspected, was dated at ca. $3365 \mathrm{cal} \mathrm{BP}$ which is younger than in the more landward part of the palaeovalley.

The eastern part of cross-section $4 \mathrm{a}$ (core 164) shows that the basal peat developed until $+3.0 \mathrm{~m}$, which is an exceptionally high level. The peat was most probably still growing in that locality, while in the rest of the area, a tidal flat was again installed.

The palaeovalley fill of the Kemmelbeek (cross-section 4b) was encountered in bore hole 988 , but the base was not reached. In the lower part of the core, the palaeovalley fill shows tidal flat sedimentation which, at least twice, silted up above high water level so that peat could develop temporarily. These peat layers occur not at the same levels as those in cross-section 3 . The well-developed peat bed (as found in cross-section 3 between $-3 \mathrm{~m}$ and $-4 \mathrm{~m}$ ) is not present here.

In the IJzer palaeovalley, the Pleistocene surface is found at about $-4 \mathrm{~m}$ in this section which is situated at the northern margin of the IJzer palaeovalley. The basal peat in bore hole 1074 is dated at ca. 7275 cal BP. Significant differences are also encountered here over short distances in the palaeovalley fill. Bore hole 1074 reveals one more peat bed and mud layer between the basal peat and the gyttja, compared to bore hole 1004 . In view of the ${ }^{14} \mathrm{C}$ dates which statistically have the same ages, the changes from mudflat to freshwater gyttja and peat growth occurred rapidly. In bore hole 1074, the top of the first intercalated peat layer is dated at ca. 7165/ $7105 / 7095$ cal BP; a similar age was obtained for the base and top of the gyttja bed in bore holes 1004 and 1074 respectively. The top of the peat layer overlying the gyttja was dated at ca. $6290 \mathrm{cal} \mathrm{BP}$ and Scrobicularia plana in the mud was dated at ca. $6285 \mathrm{cal} \mathrm{BP}$.

While gyttja and peat were accumulating for about 800 years in the IJzer palaeovalley with only a short interval of mudflat deposition, a mudflat environment was prevailing in the Kemmelbeek palaeovalley. The mud flat did not expand over both palaeovalleys until after ca. $6300 \mathrm{cal} \mathrm{BP}$, at least not along the northern margin of the IJzer palaeovalley. Within the mudflat sequence, laminated fine sand, silt and clay with no evidence of erosional surfaces, denote current activity most probably originating from a small gully (or several gullies) that drain the water from the mud flat to the major channel situated slightly to the south.

The fill of the IJzer palaeovalley was also eroded by a young tidal channel which is crossed twice in this crosssection (cores 1073 and 991, see Fig. 7). 


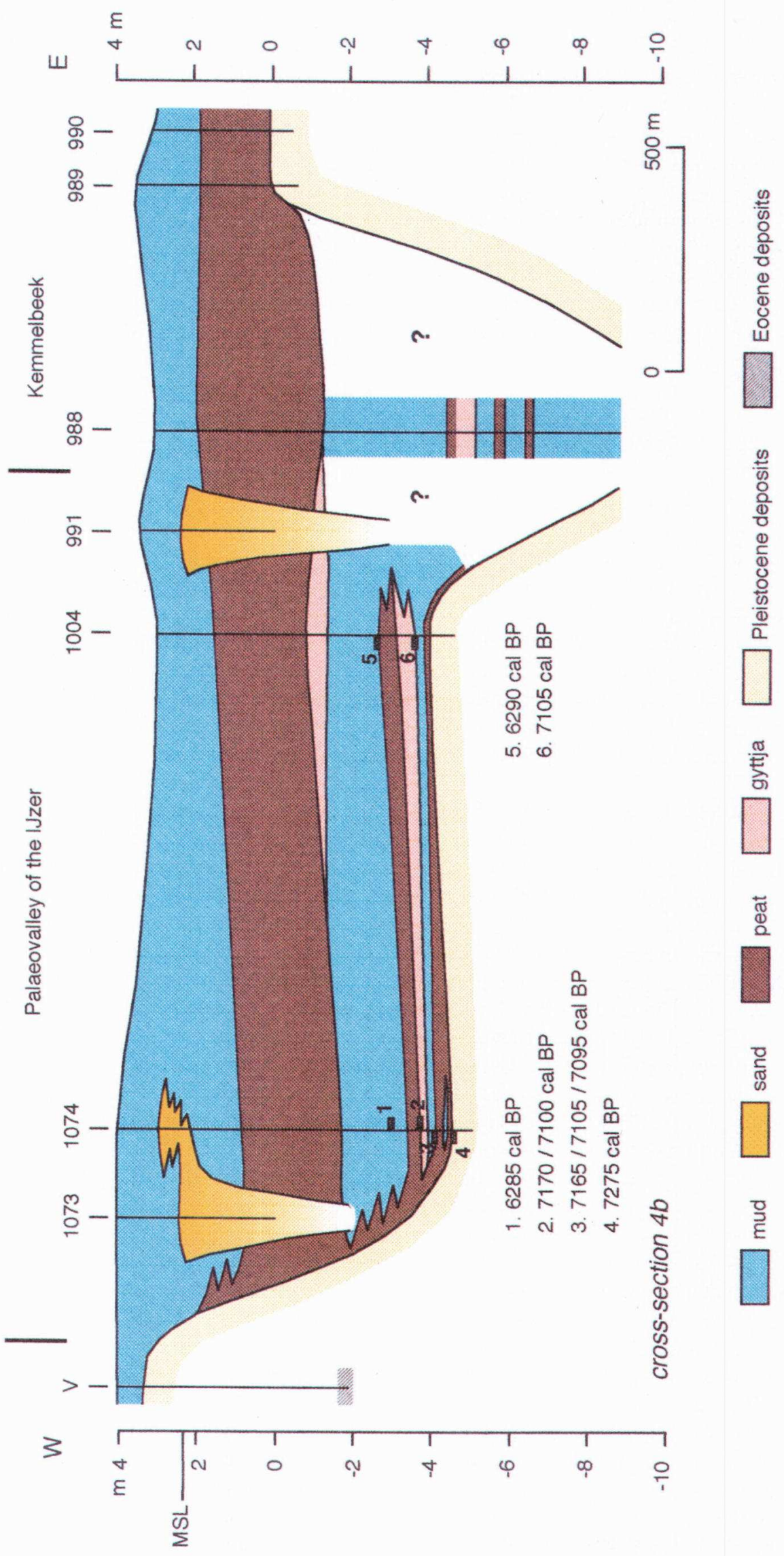




\subsection{Longitudinal sections}

The longitudinal sections were constructed to demonstrate the relationship between the stratigraphy in the southern and seaward parts, in particular in relation to the occurrence of peat beds. Only section A-A' (Fig. 12 ) is located in the palaeovalley for its major part (see Fig. 3). Section B-B' (Fig. 13) shows the seaward part outside the palaeovalley, because in the palaeovalley itself, the sedimentary sequence consists of only sand deposits from later erosion by tidal inlet and channels (Baeteman, 1993) making a relationship with peat formation impossible.

\subsubsection{Section A-A'}

The section (Fig. 12) was constructed on basis of the available bore holes displaying the thickest sequence of the palaeovalley fill, and avoiding those sites where later erosion by tidal channels removed the sequence. Therefore, it does not always represent the deepest part of the palaeovalley and the apparent undulating surface of the Pleistocene deposits should not be regarded as types of ridges, but simply results from bore holes which are located slightly higher up the valley walls of a cross-section with a strong vertical exaggeration.

This section crosses a tidal channel (bore hole $\mathrm{O}$ ) which initiated after a period of mudflat deposition covering the basal peat which is dated at ca. $9000 \mathrm{cal}$ BP. Environmental reconstruction is based on detailed palaeoecological diatom studies carried out by Denys (1993a) on bore hole O. The channel produced a $8 \mathrm{~m}$ thick aggradation during ca. 1200 years until it silted up at that particular site and changed to intertidal and supratidal flat followed by a period of peat growth in this particular location lasting ca. 200 years. By that time, the deeper part of the palaeovalley was completely filled up and more extensive accommodation space for deposition determined by the palaeotopography, became available from a level of about $-5 \mathrm{~m}$. The tidal channel became active again, its position was also confined to the palaeovalley, and according to the datings of the basal peat in bore holes $\mathrm{OK}$ and $\mathrm{S}$, mudflat deposition extends laterally in the period between ca. 8000 and $7500 \mathrm{cal} \mathrm{BP}$. This happened progressively as, according to the diatoms, the basal peat reveals a rapid change to wetter conditions, but without evidence of erosion, and the mud was deposited under conditions where a small tidal amplitude was prevalent (Denys, 1993a). At about 7200 cal BP, the area outside the palaeovalley was also filled in and peat developed until about 6700 cal BP. South of the palaeovalley, the latter lasted until about $6300 \mathrm{cal} \mathrm{BP}$.
The geometry of the various facies in this section between about $-5 \mathrm{~m}$ and $0 \mathrm{~m}$ demonstrates the effect of the tidal channel on the spatial distribution of the different depositional environments as well as on peat development. The lateral wedges of sand can be interpreted as sand flats and sand bars which are associated with the tidal channel when the latter is migrating transgressively landward (see Zaitlin et al., 1994). Comparison of the ages of the first intercalated peat bed, together with differences in level and thickness, suggests significant effect by tides at the beginning and end of peat growth. (It can be assumed that the deposits underlying the peat experienced the same degree of compaction in all these bore holes.) The ${ }^{14} \mathrm{C}$ dates of the peat bed at $-2 \mathrm{~m}$ to $-3 \mathrm{~m}$ suggest that peat started earlier at a distal position of the channel. But this must still be confirmed by further datings.

Most of this area silted up, resulting in general peat growth starting between ca. 5900 and ca. $5500 \mathrm{cal} \mathrm{BP}$, and ending at about $2200 \mathrm{cal}$ BP. At the specific position of bore hole $\mathrm{O}$, the channel remained open until ca. 5470 cal BP, although significant silting up followed by short-lived peat growth occurred at ca. 5825 cal BP. In the section, the upper peat is drawn as a continuous bed. However, during the ca. 3000 years of peat growth, channels (which were significantly reduced in size) must have remained open to drain the freshwater marsh. None of these channels were encountered in the bore holes. The ${ }^{14} \mathrm{C}$ date of the top of the peat in bore hole $\mathrm{S}$ denotes an extremely young age of ca. 1080 cal BP. It is suspected of being contamined by modern rootlets (Baeteman and Van Strydonck, 1989), but it could also represent a specific and local situation such as a "peat island" surrounded by mudflats (Denys, 1993a).

\subsubsection{Section B-B'}

This section (Fig. 13) is characterised by two massive bodies of sand. The body of sand in the centre forms part of a tidal channel sequence. The sands erosively overly the early Holocene tidal-basin mud and the Pleistocene deposits. (The same meandering channel is crossed twice by the section). Inter-channel mudflats developed on the channel sand from the level of about $-6 \mathrm{~m}$ which is the same level from which the first intercalated peat beds occur outside the channel area. According to the age of an intercalated peat bed at $2.5 \mathrm{~m}$ (bore hole Wo), this happened prior to ca. 7300 cal BP. With the exception of the upper peat bed in the southern part of this section, intercalated peat beds are scarce and badly developed. This is not due to erosion, but results from unfavourable peat growth conditions, e.g. the daily tidal flooding associated with sediment deposition related to the proximity of the tidal 


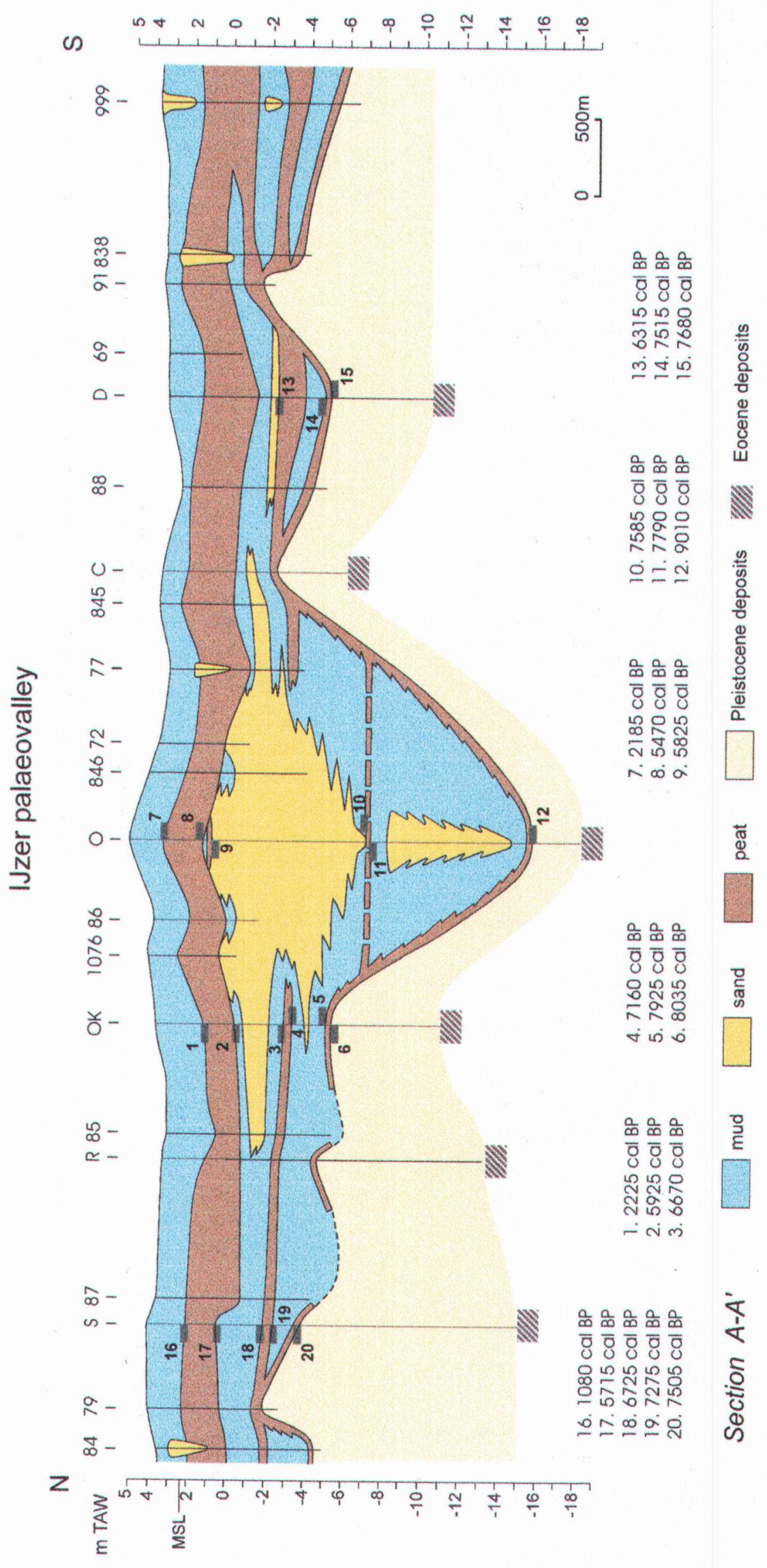

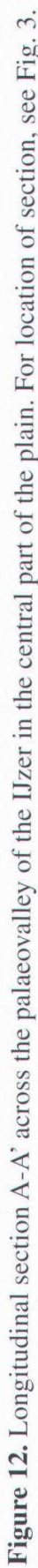




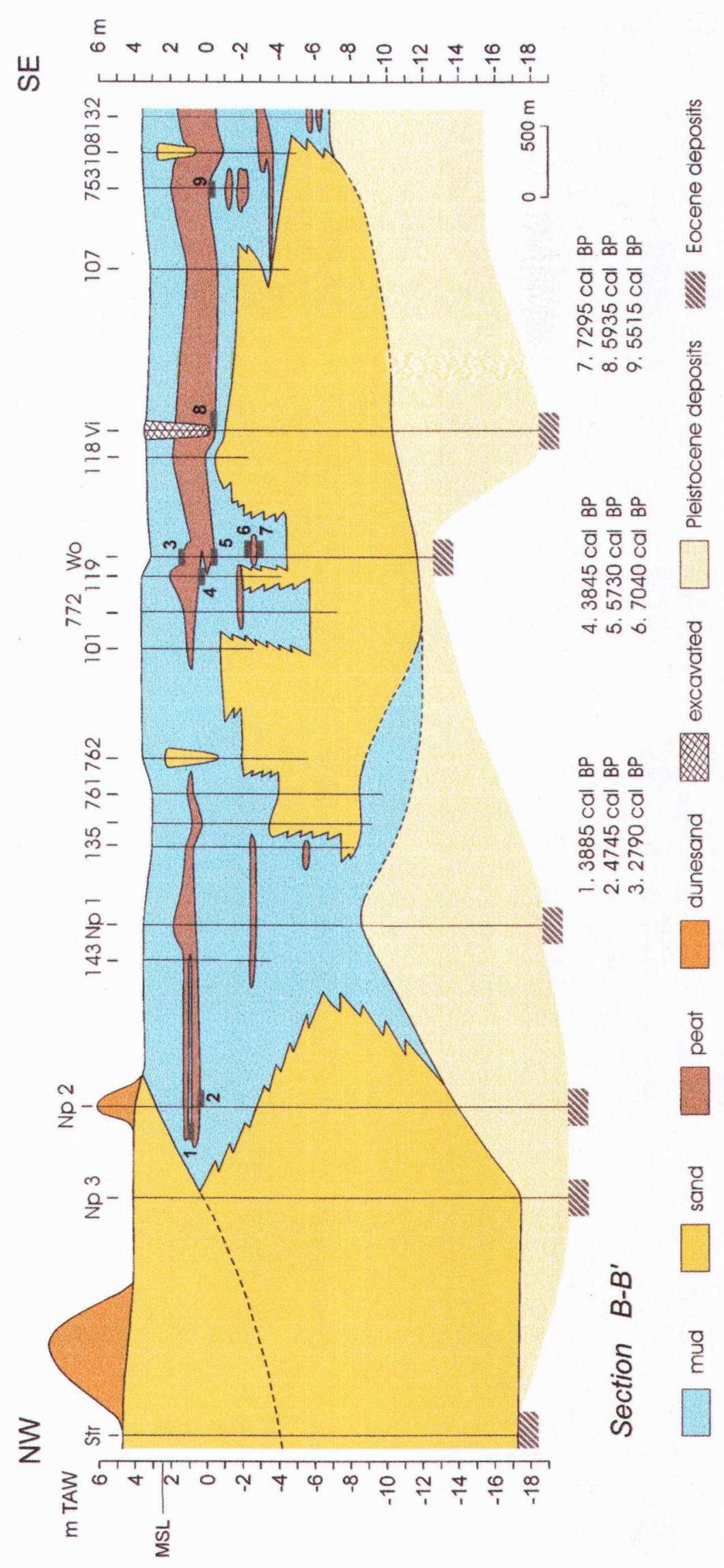

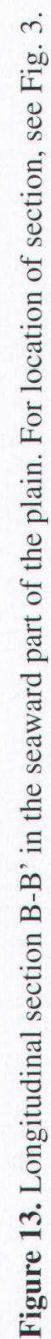


channel. Mudflat deposits with phases of silting up are only encountered from a level of about $-2 \mathrm{~m}$ and most of the channel also silted up or changed position. This was followed by general peat growth from ca. 5900 cal BP. In bore hole Wo, peat growth was locally interrupted at about $3850 \mathrm{cal} \mathrm{BP}$.

The very seaward part of the section is characterised by a thick body of sand eroding deeply into the Pleistocene deposits. At bore hole Str (located on the beach), the Pleistocene deposits are completely eroded. The base of the sand consists of a heterogeneous mixture of marine sand with fine gravel, shells from the open sea and pebbles of peat and Eocene clay. In the lower part, the sand shows internal erosion surfaces with numerous shells from the open sea and lags composed of fine gravel, as well as bi-directional crossstratification, all of which denote a high-energy environment. The sand body is most probably a tidal inlet deposit which eroded the early Holocene tidal-basin deposits. From about $-10 \mathrm{~m}$, the characteristics of the sand change in bore hole Str. Mud and silt content increases, and flaser bedding becomes predominant. Strong bioturbation occurs in cm-thick silty mud laminae also denoting tidal bedding. The number of shells decreases considerably. This part of the sand body has been interpreted as intertidal sandflats and sand bars extending along the tidal channel which progressively filled up because of the northward shift of the inlet. As the channel came from the north, it most probably remained open much longer at locations Np3 and Np2 where shells from the open sea are found throughout the entire sand sequence together with Cerastoderma edule. The change from tidal channel to intertidal deposits indicates that the transgressive landward migration of a tidal inlet with shoreface erosion stopped, and that in situ fill of the tidal basin occurred while the shoreline stabilised (see Dalrymple et al., 1992). The intertidal sand is overlain by intertidal mud from $-3 \mathrm{~m}$ in bore hole $\mathrm{Np} 2$, thus indicating the development of a mudflat in seaward direction. The mudflat silted up high enough so that peat growth could start at ca. 4745 cal BP, with local flooding also occurring here at ca. 3885 cal BP. The vertical sequence of sandflats overlain by mudflats with peat growth confirms that the transgressive landward migration completely stopped and shifted to a progradation of the shoreface.

The final fill of the tidal basin consists of mudflat and tidal channel deposits which ultimately became saltmarsh deposits. However, in the extreme seaward part, from a level of $-4 \mathrm{~m}$, nearshore and beach deposits are erosively overlying the sandflat, sand-bar and mud deposits. They can be traced about $2.5 \mathrm{~km}$ inland where they narrow. At this location, the base of the nearshore and beach deposits is formed by a lag consisting of lumps of peat and clay, shells from the open sea and the tidal flat, and fine gravel. This erosional surface is most probably produced by waves during a landward retreat of the shoreface as the latter migrates inland (see Zaitlin et al., 1994; Allen and Posamentier, 1993).

It is interesting to mention that the studies originally defining the Calais and Dunkerque deposits (Dubois, 1924) were carried out in a similar seaward portion of the coastal plain characterised in the lower part by erosion which removed almost all previous early Holocene records, followed by silting up and progradation. Therefore, the stratigraphy based on Calais and Dunkerque does not reflect the true depositional history of the plain.

\section{Discussion}

The cross and longitudinal sections show a high variability of the Holocene sedimentary succession. The differences are expressed across and along each palaeovalley fill itself, between the different palaeovalleys, and between the various sub-regions, i.e. landward, central and seaward parts.

\subsection{Comparison within the 3 palaeo-valleys in the landward part.}

Although the entire Holocene sequence is only recovered in one bore hole in the Sint Jansbeek, it demonstrates that the extreme landward part of this particular area was already within tidal reach from about 7800 cal BP. The alternation of phases with current activity and phases of silting up in the tidal deposits indicates that the sedimentation did not happen continuously, nor gradually. This tends to suggest alternative phases of sediment supply to the area.

The facies succession in the Kemmelbeek shows a high variability across as well as along the palaeovalley fill. Gyttja is prevalent in the extreme landward part, where tides apparently gained access from ca. $6200 \mathrm{cal} \mathrm{BP,}$ i.e. about 1500 years later than in the Sint Jansbeek. In the area covered by cross-section 2, no tidal deposits whatsoever were encountered in the bore holes. In view of the tidal deposits more landward, intertidal mud should be present somewhere around $-3 \mathrm{~m}$ to $-2 \mathrm{~m}$. An even denser boring grid would certainly reveal this. In any event, this indicates that the tidal effect was weak.

The gyttja in the Kemmelbeek is progressively replaced by mudflat deposits and peat beds along the course of the valley in a northerly direction. However, a regular pattern neither exists in the vertical succession of gyttja, 


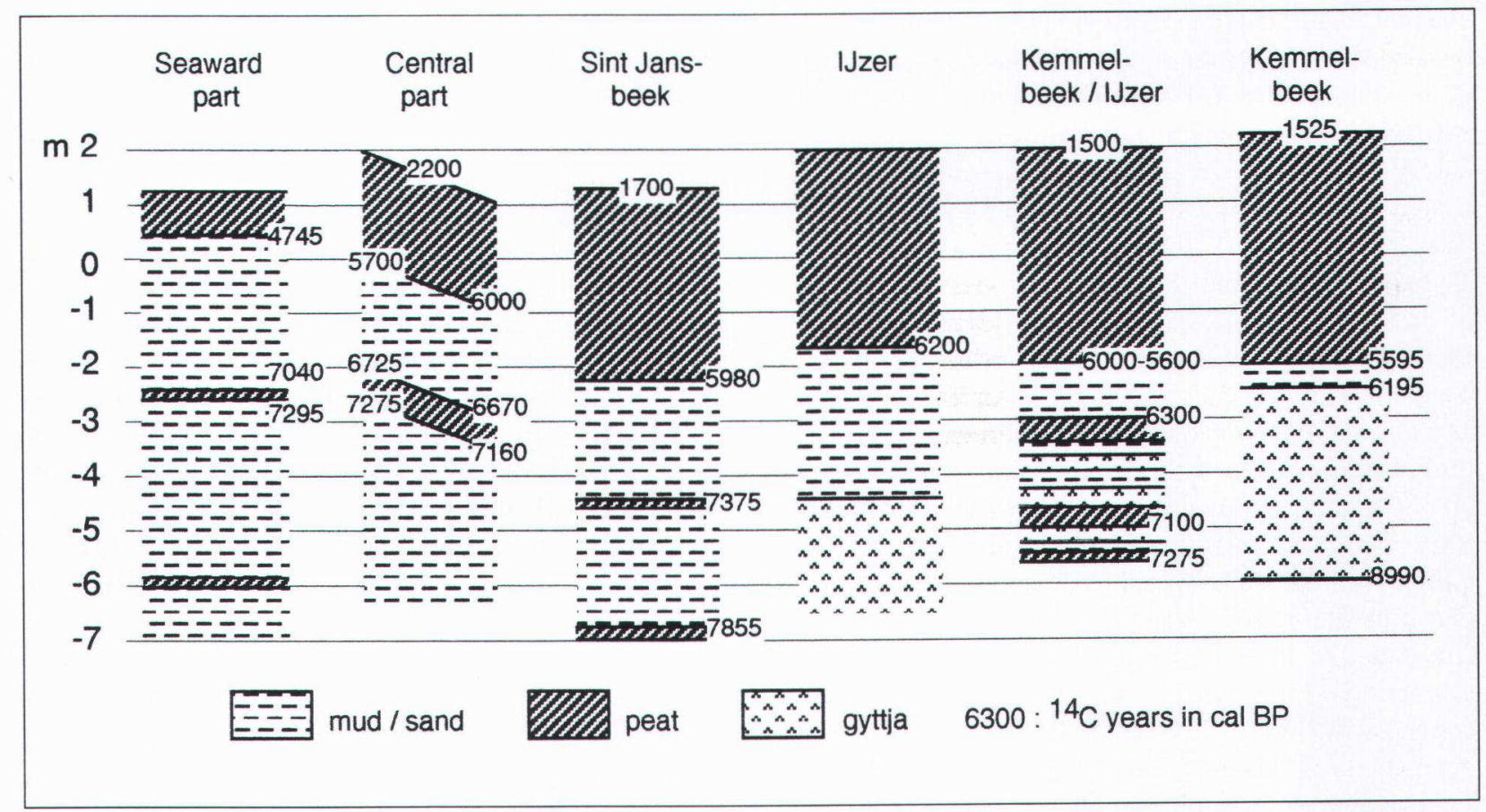

Figure 14. Radiocarbon ages of peat/gyttja-mud/sand contacts in the palaeovalley fills of the Kemmelbeek, Sint Jansbeek and IJzer with respect to altitude and compared to the contacts in the central and seawards parts of the coastal plain.

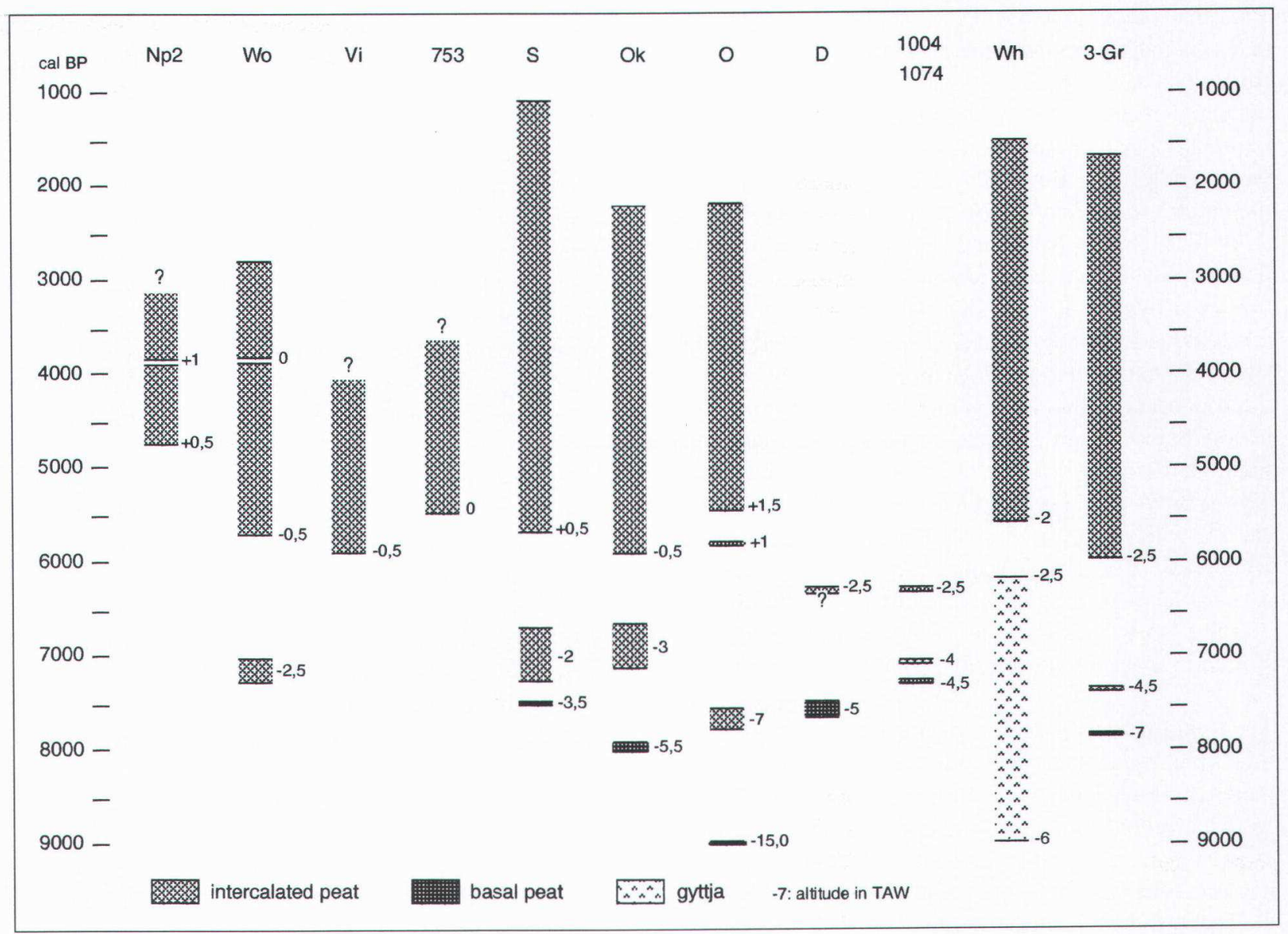

Figure 15. Comparison of the altitude of the basal peat, intercalated peat and gyttja contacts with clastic deposits in the discussed bore holes presented in a time frame showing no regularity concerning age and altitude. 
peat and mud, nor along or across the valley fill, and certainly not in the section below ca. $-3 \mathrm{~m}$. The number of intercalated peat beds also varies. Even after considering compaction which may have lowered the initial level to some degree, the cross-sections obviously depict no regular or generalised level at which specific intercalated peat beds formed. The landward part of the IJzer palaeovalley also shows a similar irregular vertical and lateral facies distribution of gyttja, peat and mud until the level at about $-3 \mathrm{~m}$. Moreover, the ${ }^{14} \mathrm{C}$ dates here indicate that the changes in facies, or alternation happened very rapidly. Besides, it is highly probable that mudflat deposition prevailed in the Kemmelbeek (see core 988) while at the edge of the IJzer valley only peat and gyttja accumulated during the period between ca. 7100 and 6300 cal BP after a thin layer of mud was deposited (unless a lowering of the original level by about $2 \mathrm{~m}$ due to autocompaction is to be considered in core 988 which is most inconceivable). The Sint Jansbeek on the other hand, is characterised by only mudflat deposition during this period.

However, from a level of ca. $-3 \mathrm{~m}$, the rapid alternation of gyttja, peat and mud disappears and $1 \mathrm{~m}$ thick mudflat deposits are widespread throughout the three palaeovalleys. According to the ${ }^{14} \mathrm{C}$ dates of the IJzer palaeovalley, this happened from ca. $6300 \mathrm{cal} \mathrm{BP}$ onward. This widespread extension of mudflat deposition coincides with the first tidal effect encountered in the extreme landward part of the Kemmelbeek (core Wh, cross-section 1) which was dated at ca. $6200 \mathrm{cal}$ BP.

The mud is overlain by a 3 to $4 \mathrm{~m}$ thick peat bed at a level between $-2 \mathrm{~m}$ to $-1 \mathrm{~m} .{ }^{14} \mathrm{C}$ dates for the base of this peat bed are only available in the extreme landward part of the three palaeovalleys: ca. $5980 \mathrm{cal}$ BP (Sint Jansbeek), ca. 5595 cal BP (Kemmelbeek) and ca. 6195 cal BP (IJzer, core 1057, not in the crosssection, about $1 \mathrm{~km}$ to the west of core $\mathrm{V}$, cross-section 4b). These dates once again confirm that facies changes are not synchronous. The ${ }^{14} \mathrm{C}$ date for the beginning of peat growth in the Sint Jansbeek e.g. coincides with the maximum of tidal effect in the Kemmelbeek. When tidal deposition started in the Kemmelbeek, peat began to grow in the extreme landward part of the IJzer palaeovalley.

\subsection{Comparison between the land-ward and central part}

Section A-A' shows the main IJzer palaeovalley and crosses the deposits of a tidal channel which, together with its adjoining intertidal flats occupies the entire palaeovalley. The thick gyttja accumulations and the rapid alternation of mud, gyttja and peat are certainly not evident as these are characteristic for the distal part of the tidal basin. On the contrary, two peat beds intercalated in mud occur, showing a rather regular and widespread pattern. The lowermost intercalated peat bed at $-7 \mathrm{~m}$ was encountered in only one bore hole which does not constitute enough evidence to give a firm conclusion. The area outside the palaeovalley is progressively occupied by tidal flat deposits which accreted until $-3 \mathrm{~m}$ to $-2 \mathrm{~m}$. The time when the mud deposition started is determined by the palaeotopography of the Pleistocene subsoil and occurred between ca. $7925 \mathrm{cal} \mathrm{BP}$ and ca. $7500 \mathrm{cal} \mathrm{BP}$. During this period, only the Sint Jansbeek experienced intertidal mud deposition (between ca. $7855 \mathrm{cal} \mathrm{BP}$ and ca. $7375 \mathrm{cal}$ $\mathrm{BP}$ in the extreme landward part). The Kemmelbeek, on the other hand, was characterised by only gyttja accumulation. But, when the elevation is also taken into account, the section between $-6 \mathrm{~m}$ and $-3 \mathrm{~m}$ is occupied by rapid alternations in mud, gyttja and peat in the northern part of the Kemmelbeek and in the landward part of the IJzer (see cross-sections 3 and 4). In the latter, the sequence of rapid alternation is dated between ca. $7300 \mathrm{cal} \mathrm{BP}$ and ca. $6300 \mathrm{cal} \mathrm{BP}$. However, the Sint Jansbeek still reveals a different sequence, since the first peat bed intercalated in mud is encountered at $-4.5 \mathrm{~m}$ and dated at ca. $7375 \mathrm{cal}$ BP. The differences of facies changes with respect to elevation is demonstrated in Fig. 14. Fig. 15 shows the altitude of basal peat, gyttja and intercalated peat beds versus a time frame. No regularity concerning age and level can be observed either.

The change from mud to peat in the central part is encountered at a rather regular level between $-3 \mathrm{~m}$ and $2 \mathrm{~m}$. However, as described above for the landward part of the three palaeovalleys, the level between $-3 \mathrm{~m}$ and $-2 \mathrm{~m}$ corresponds to a widespread extension of intertidal deposition. The latter happened after ca. 6300-6200 cal BP, while the change from mud to peat at a similar level in the central part, occurred almost 1000 years earlier, i.e. between ca. $7275 \mathrm{cal} \mathrm{BP}$ and ca. 6960 cal BP (see Fig. 14).

The marked differences in ages and elevation of the facies changes cannot be solely attributed to compaction. The peat and gyttja beds that were dated at ca. $7100 \mathrm{cal}$ BP in the palaeovalley of the IJzer e.g. (see cross-section $4 \mathrm{~b}$ ) only lie ca. $40 \mathrm{~cm}$ above the relatively consolidated Pleistocene deposits. It is therefore inconceivable that compaction of the mud and peat lowered their level significantly. On the contrary, the peat bed occurring at $-2 \mathrm{~m}$ to $-3 \mathrm{~m}$ in the central area could have originated at a somewhat higher level in view of the ca. $4 \mathrm{~m}$ of underlying mud.

In the central part, a widespread and $2 \mathrm{~m}$ thick tidal deposit overlies the peat bed occurring at -3 to $-2 \mathrm{~m}$. 
This tidal deposit changes to another peat bed at the level of ca. $0 \mathrm{~m}$. This peat bed is well-developed and is evenly distributed. It is usually called the surface peat. The dates of the start of peat formation here are: ca. 5925,5715 and 5470 cal BP which are very similar to the dates in the very landward part where the transition from mud to peat is found about $2 \mathrm{~m}$ lower (see cross-section 1).

The tidal channel deposits in the central part exhibit a slightly different situation. The tidal effect which regained access after a short period of peat growth at the site of core $\mathrm{O}$, indicates that the tidal channel was still actively depositing somewhere nearby.

\subsection{Comparison with the seaward area}

The intercalated peat beds here are scarce and discontinous. The deepest beds are found around -6 $\mathrm{m}$, which is slightly higher than in the central part. From section B-B', it is clear that the formation of intercalated peat beds is directly related to the decrease in lateral extension of the tidal channel deposits which is encountered from a level of $-6 \mathrm{~m}$. As the channel continues to progressively silt up and decreases its lateral extension, more intercalated peat beds could form, but still only locally. The peat bed at $-3 \mathrm{~m}$ to $-2 \mathrm{~m}$ is found in only a few bore holes. The level coincides with the level at which the channel is almost completely silted up. The peat bed was dated in only one bore hole. The base (ca. $7295 \mathrm{cal} \mathrm{BP}$ ) is slightly older than in the central part. The date from the top (ca. $7040 \mathrm{cal}$ $\mathrm{BP}$ ) suggests that is was very short-lived, and was replaced by an intertidal environment more than 600 years earlier than in the central part.

According to section B-B', the channel silted up at this site at a level of about $-1 \mathrm{~m}$, and the area changed into intertidal flat. It is self-evident that a channel was still open somewhere nearby, otherwise no mud could have been deposited in the intertidal environment. A much denser boring grid is required to reveal the remaining channel. In any event, the available bore holes leads us to believe that the channel was very much reduced in lateral extension.

Eventually the major part of the area silted up into the supratidal zone as peat started to develop. In the southern part of the section, the level and date when the peat started growing are rather similar to the central part. The younger age in bore hole 753 (ca. $5515 \mathrm{cal}$ $\mathrm{BP}$ ) coincides with the date of the renewed peat growth on the tidal channel fill in the central part, suggesting that the active sedimentary surface at that particular site was still within the reach of the tidal channel.
The peat bed thins considerably in a seaward direction, thus indicating less favourable conditions for peat growth due to significant tidal deposition. In view of the ${ }^{14} \mathrm{C}$ date in bore hole $\mathrm{Np} 2$ (ca. 4745 cal BP) the tidal effect was evident there for a much longer time. The slightly higher level of the base of the peat bed also suggests that mudflat accretion was more substantial and/or lasted longer. Moreover, the temporary flooding of the freshwater marsh confirms that tidal activity and sedimentation continued in the areas very nearby.

\subsection{Factors controlling the formation of intercalated peat beds}

Intercalated peat beds originate when the active sedimentary surface builds up high enough that it is permanently situated above the level of the highest astronomical tide (HAT) resulting in the formation of a freshwater marsh in which peat can accumulate provided that the sediment surface remains saturated throughout its formation (e.g. Denys, 1993a, Allen, 1995, Stone and Gleason, 1981). However, the initiation of peat in a freshwater marsh requires the installation of a freshwater lens in the subsurface for a duration sufficiently long, otherwise only humic vegetation horizons will be allowed to exist due to the dense salt-marsh vegetation introducing a lot of organic matter into near-surface deposits (Stone and Gleason, 1981).

Unlike autochtonous peat, gyttja is formed by plant remnants which have been physically moved from a somewhat distant source, most likely the vegetation lining influent rivulets. The formation of gyttja must be attributed to ponding and sluggish drainage in the topographic depressions where water is backed up in the drainage channels of the palaeovalleys. The latter had no significant slope and acted as a drain for the outcropping Pleistocene hinterland. Gyttja formation also denotes inadequate sediment supply, so that the sedimentary surface could not accrete upwards in pace with the water level. Consequently, the initiation of peat on gyttja implies a lowering of the water level with respect to the sedimentary surface, most likely caused by an improvement of the drainage. This is in contrast with the initiation of peat on the salt marsh where vertical accretion of sediment is the determining factor. Consequently, changes between gyttja and peat reflect temporary changes in the local hydrology within the drainage channels in the palaeovalleys.

The comparison of the facies changes and their chronology within the palaeovalleys and between the different areas clearly demonstrates that a general 
synchroneity or regular distribution pattern does not exist at particular levels throughout the entire area, at least not until ca. $5500 \mathrm{cal} \mathrm{BP}$, and not until a level of about $0 \mathrm{~m}$ (period and elevation at which the plain was almost completely filled). Throughout the whole period before $5500 \mathrm{cal} \mathrm{BP}$, the area was characterised by a variety of facies ranging from tidal-channel sand, intertidal mud and sand, peat and gyttja; all occurring next to each other.

The observed facies changes and their chronology suggest that the changes are directly related to the position of the active sedimentary surface with respect to the water level. The sedimentary surface is determined by the sediment supply which, in turn, is governed by the sediment source, while the water level depends on the tidal and groundwater level, both of which are induced by the level of the sea.

The tidal flat is dissected by a very extensive network of tidal channels and creeks (in the supratidal zone) acting as local sediment sources. When the sediment supply surpasses the creation of accommodation space by RSL rise, the area will rapidly silt up until highwater level. Consequently, the frequency of tidal inundation decreases and a part of the drainage network serving that particular area becomes redundant and silts up. Eventually the area becomes out of the reach of tidal inundation and the salt marsh encroaches the mudflat, followed by peat accumulation if sufficient time is available for the formation of a freshwater lens in the subsoil. However, at the same time, intertidal deposition continues in an adjoining part of the peat area until it, in turn, will also build up above highwater level and will experience the same evolution.

But the rapid RSL rise steadily created more accommodation space (i.e. an increasing tidal prism) for the channels which experience a headward growth together with a rise of the water level. Those areas where peat was forming, were deprived of sediment accumulation for a few hundred years, resulting in their active sedimentary surface being lower in relation to the surface of the tidal flat flanking the channel. Consequently, these areas are in a location that is extremely prone to being flooded when the channel shifts its position.

The latter is probably not solely caused by the mechanism of lateral channel migration whereby erosion takes place in the outer bend of the channel and deposition in the inner bend because, according to van der Spek and Beets (1992), lateral migration is limited when storage capacity is continuously created. The geometry of the sand deposits as depicted in section A-A', and the lack of erosional features lead us to assume that crevasse splays as well as meander cut-offs caused the shifts in the position of the channels. These mechanisms were initiated by the water level steadily rising, and by the high aggradation in the channel which considerably reduced the storage capacity for sediment in the channel itself. The high aggradation in the channel or in a segment of it resulted from a decrease in the size of the tidal prism of a part of the channel network due to surface elevation of its surrounding flats. The necessary storage capacity for the channel to compensate the surpassing sediment supply was however available in the lower-lying surroundings of the channel (segment) where peat was forming. Such crevasse splay deposits, almost instantaneously filling the lower-lying surrounding areas of a channel, have been observed in an open sand pit (Baeteman et al., 1999).

The drowning of the freshwater marsh due to the shift in channel position did not occur gradually. The water level rose above the surface rather suddenly, thus preventing a salt marsh from initiating and accreting upwards in pace with the water level. On the other hand, sediment import was sufficient to maintain the intertidal flats.

The imbalance between RSL rise and sediment supply leading to the formation of gyttja in the landward part of the palaeovalleys resulted from the silting up of the tidal flat in more downstream areas preventing the sediment source from reaching the area, or simply because the channel and creek network had not yet reached the area. Moreover, it is most probable that a higher water level was enhanced by the blockage of run-off from the Pleistocene hinterland by the formation of peat itself in the more downstream parts of the drainage channels. The accumulation of organic matter was most probably enhanced by fluvial processes, although with less activity. Moreover, formation of gyttja was greatly affected by the rising base level, because the rapid RSL rise at prior to ca. $7000 \mathrm{cal} \mathrm{BP}$ was causing a change in stream slope and drainage characteristics in the landward palaeovalleys. In the case of the Kemmelbeek, a Pleistocene ridge prevented all tidal access until ca. 6200 cal BP.

Peat accumulation on gyttja could start as soon as the superfluous water was evacuated. This was caused by the approach of a tidal channel by landward migration and/or shift (while accumulating), resulting in the disappearance of the blockage, and consequently, better drainage.

The mechanisms of meander cut-offs and crevasse splays resulting in the take-over of drainage of one channel system by another, or the change to a quite different course, can result in the abandonment of a channel, or a segment of it, which is then filled within a relatively short period (months to years) (Oost and de Boer, 1994, van den Berg, 1982). If sediment im- 
port is sufficient to balance the RSL rise, such areas aggradate from the subtidal into the intertidal environment, evolving into salt marsh, and eventually into freshwater marsh with peat accumulation.

From the discussion above, it follows that the alternation of mud, peat and gyttja, and the occurrence of the different sedimentary environments next to each other at the same time and even over very short distances, is solely determined by sedimentological control. The change of one environment into another, laterally as well as vertically, is related to the distal or proximate position of the channels and creeks, even on a small scale.

The shift of the channels alternately serving and abandoning a particular part of the flat continues as long as new accommodation space is steadily being created by the rapid relative sea-level rise, so that the entire channel network can continue to migrate landwards and upwards. It is self-evident that sediment supply must outrun the creation of accommodation space, otherwise silting up would not occur in the channels, nor would the flats silt up each time to the supratidal level.

With a decreasing rate of RSL rise, the creation of new accommodation space progressively reduces, and the vertical sediment accretion in the channel and on the flats slows down. This results in a reduction in the frequency of channel shifting and explains why the periods of peat growth lasted longer, and why the lateral extension became more and more generalised as the filling of the tidal basin proceeded.

Allen (1997) also attributed the alternation of mud and peat to changes in the channel and creek network whereby mud deposition coincides with an expansion of the network and peat development with shrinking of the network and silting up of the channels and creeks. However, the author correlates the alternating expanding and shrinking with sea-level fluctuations. Expansion occurs during a sea-level rise, and shrinking occurs when the sea-level temporarily stabilises or falls.

However, when sea-level fluctuations are the cause of the changes in the channel network, the various intercalated peat beds should be much more synchronous, even after taking a certain time lag between sea-level fluctuations and lithological registration into account. Moreover, in view of the rapid facies changes which were observed in the landward part of the palaeovalleys in the study area, the sea level should have been continuously fluctuating. A sea-level fall must be ruled out since, in this case, new accommodation space would no longer be created, and the landward migration of the channel network would stop. This implies that the channels no longer need to shift frequently in order to search for space, and alternate peat beds and mud would not be formed. A sea-level fall would also lower the groundwater level and the sediment surface would no longer remain saturated, which is a very unfavourable condition for peat to accumulate.

\section{Depositional history of the IJzer palaeo- valley}

The depositional history, as recorded in the study area, can be divided into 4 major periods which are not established on basis of rigid time control, but more on the basis of changes in dominance of the factors controlling the infill.

\subsection{Period before ca. 7800 cal BP}

The filling of the plain starts in the seaward area at the earliest from ca. $9400 \mathrm{cal} \mathrm{BP}$ (see Fig. 6), which is the age of the oldest known basal peat in the seaward part of the IJzer palaeovalley (Baeteman and Denys, 1997). This is in contrast with the generally accepted view in the Belgian literature where it is stated that the first transgression occurred between 6450-4750 BP (i.e. ca. 7300-5500 cal BP, e.g. Maréchal, 1992a). The rising sea invaded the area via the palaeovalley in which tidal flat and channels developed. In the landward area, rivulets, confined to the palaeovalley tributaries, drained the freshwater run-off. However, the relative sea-level rise induced a rise of the base level, hampering the drainage and causing the formation of gyttja in the depressions of the palaeovalleys. This was especially the case for the Kemmelbeek. Because of the rapid RSL rise by an average of $7 \mathrm{~m} / \mathrm{ka}$, the flooding occurre rapidly but, in view of the presence of the basal peat, not as an erosional event. Although the subsoil of the palaeovalley consists of soft, easily erodable sediments, its topography is well preserved because, due to the rapid RSL rise, accommodation space is being created, rather than lost. This contradicts Houthuys et al. (1993) specifying an erosional relief for the Pleistocene subsoil.

The rapid RSL rise resulted in a rapid landward shift of the tidal facies belts across the palaeovalley, since by ca. $9000 \mathrm{cal} \mathrm{BP}$ and ca. $7800 \mathrm{cal} \mathrm{BP}$, tidal flat and channels were installed in the central and landward part, respectively. In the latter, only the eastern tributary of the palaeovalley shows tidal deposition. This resulted from a Pleistocene ridge in between the Sint Jansbeek and the Kemmelbeek which prevented the tides to reach into the western tributary. In the Kemmelbeek, gyttja accumulation persisted until ca. $6200 \mathrm{cal} \mathrm{BP}$. The minor portion of fluvial deposits demonstrates that fluvial sedimentary processes only played 
a minor role during the transgressive fill of the palaeovalley. On the other hand, the reduced fluvial action most probably enhanced the accumulation of organic matter.

By ca. 7800 cal BP peat formed on supratidal mud on top of channel sands indicating that sufficient sediment was supplied to balance the RSL rise. The sediment was supplied by shoreface retreat and was accompanied by the landward migration of tidal inlets and channels. The shoreline was probably located far beyond the present-day coast. However, the steady landward migration of the tidal system eroded the early Holocene basal peat and intertidal deposits in the seaward part of the palaeovalley, and replaced them by tidal-inlet and channel sand. No dates are yet available in the study area for determining exactly when the shoreface reached the position of the present-day shoreline.

Although sediment supply was available, the rate of RSL rise that steadily enlarged the tidal prism of the channel network was too rapid, so that the active sedimentation surface of the flats did not silt up until supratidal levels lasting a sufficiently long period, thus not enabling a freshwater lens to form in the subsoil. Consequently, no freshwater marshes could form. This explains the complete absence of intercalated peat beds in the sedimentary sequence deposited in the period prior to ca. $7800 \mathrm{cal} \mathrm{BP}$.

\subsection{Period between ca. 7800 and ca. 6000 cal BP}

This period is characterised by a retardation in the rate of RSL rise to an average of $2.5 \mathrm{~m} / \mathrm{ka}$ at about 7500 7000 cal BP. According to the sea-level curve (Fig. 5, Denys and Baeteman, 1995), the relative sea level rose from about $-8 /-6 \mathrm{~m}$ to $-2.5 /-1.5 \mathrm{~m}$ during this time interval. This still caused a substantial landward migration of the tidal system (see Fig. 6).

Because of the reduced rate of RSL rise, the sediment supply easily balanced the creation of accommodation space, and the general landward migration of the channel network was characterised by a high vertical sediment accretion in the channels and in their immediate adjacent flats. Relative large sediment supply caused rapid silting up of the flat to supratidal level and forced the channels (or segments of it) to shift course and position by lateral migration and/or avulsion resulting in the alternate draining and abandoning of specific parts of the tidal basin, and this occurred at a higher level each time. Abandoned flats and channels evolved into freshwater marshes with peat accumulation, while freshwater swamps, situated on a somewhat lower level, came within the direct reach of the new course of the channel, and changed rapidly into intertidal flats until they, in turn, rose to supratidal level, followed by another shift of the channel or a segment of it.

By ca. 6300 cal BP, the tidal basin reached its maximal extension even in the landward parts of the palaeovalleys where the rivulets, formerly acting as freshwater drains, were consumed by tidal channels. However, this eventual change took place in successive steps whereby, from ca. 7300 cal BP, intertidal and supratidal flats, freshwater swamps and freshwater-filled depressions existed next to each other, even over very short distances, resulting in a rapid alternation of mud, peat and gyttja in the sedimentary sequence. The occurrence of the various environments next to each other resulted from the position of the active sedimentary surface with respect to the water level which was controlled by the distal or proximate position of a particular site with respect to a channel segment, i.e. to the local sediment supply. A proximate position brought the active sedimentary surface within the reach of the daily tidal flooding enabling the surface to rise until it reaches supratidal level. A distal position provided the opportunity for peat to initiate and accumulate on the supratidal flat, while a deprivation of sediment drowned the surface thus allowing gyttja accumulation.

This purely sedimentological mechanism, acting only under conditions of a rapid RSL rise and a general landward migration of the channel network, is at the origin of the alternation of peat beds, gyttja and tidal sediments. It also explains why the intercalated peat beds are not synchronous and do not exhibit a regular pattern in terms of level and spatial distribution.

Thus, a single peat bed should not be used as marker bed in the stratigraphy, nor as stratigraphic unit. Nor does the alternation of mud and peat reflect positive or negative sea-level tendencies, since sea-level fluctuations play no part in their formation. The sea-level tendencies were introduced and used as a chronological basis for the subdivision of the Holocene sequence in the Fenland (UK) by Shennan et al. (1983) and Shennan (1986) whereby positive sea-level tendencies are characterised by a rise in sea level, development of transgressive overlaps and a landward movement of the coastline. Negative sea-level tendencies are characterised by the development of regressive overlaps (peat beds), a seaward movement of the coastline, and a reduced or negative rate of sea-level rise.

By 7500 cal BP, the deeper part of the main palaeovalley was almost completely filled in the central portion of the plain (see Fig. 6). The higher parts of the Pleistocene subsoil, covered with basal peat, came within the reach of the tidal system. This resulted in a substantial extension to the accommodation space for the chan- 
nel network, requiring a very large volume of sediment for the silting up. However, the sediment supply was sufficient to maintain the intertidal flat, but not sufficient to frequently build to a height of supratidal levels. This explains why the rapid alternation of peat beds and mud is not evident, and why only one intercalated peat bed could form during this period in the central part. The (less frequent) meander cut-offs and/or crevasse splays of the channel here resulted in the deposition of sand bodies intercalated in the mud.

This situation should not be generalised for the entire coastal plain. In the Veurne area e.g. (located seawards, a few $\mathrm{km}$ west of the IJzer palaeovalley), the period between ca. 6700 and ca. $5550 \mathrm{cal} \mathrm{BP}$ is characterised by an episode of non-deposition (Baeteman et al., 1999) confirming that the palaeotopography of the Pleistocene subsoil is also one of the major factors controlling the Holocene sedimentary sequence.

The silting up to supratidal level with the accumulation of peat are not synchronous within the central part. Differences in time are also evident if we compare the central part with the seaward part. The differences in age are also attributed to the distal or proximate position of a specific part of the tidal flat in relation to the channel. The younger date of the peat on the channel fill itself indicates that the latter still remained open for about 500 years. Its effect also prevailed in the western tributary of the palaeovalley where peat growth started at about $5600 \mathrm{cal}$ BP unlike in the eastern tributary where it started at ca. $6000 \mathrm{cal} \mathrm{BP}$, thus providing additional evidence that the eastern tributary was abandoned by the tidal channel in that period.

The differences in age concerning the formation of peat beds is particularly evident in the seaward part where it is clear that the formation of peat beds is related to a decrease in the lateral extension of the channels due to a slower RSL rise and a less rapid landward migration of the channel network. However, substantial accretion of vertical sediment still occurs.

Towards the end of this period, the landward migration of the channel network eventually stopped because new accommodation space was no longer being created by the slower RSL rise, leading to shoreface stabilisation and in situ filling of the tidal basin. This resulted in substantial shrinking of the channel network in the landward and central parts, leading to a general initiation of another peat bed (the surface peat) from about $6000 \mathrm{cal}$ BP onward. However, in the seaward areas, the active sedimentary surface had not yet built up to supratidal levels, thus explaining the continuation of the vertical accretion of intertidal deposits, while in the landward and central parts, peat accumulation could keep pace with the relative sea-level rise.

\subsection{Period between ca. 6000 and ca. $4000 / 1500$ cal BP}

By ca. 5500-5000 cal BP, the rate of relative sea-level rise fell to an average of $0.7 \mathrm{~m} / \mathrm{ka}$. Sea level was then at a level of 0/+1 m TAW. An adequate supply of sediment was apparently still available, and it even overran the rate of relative sea-level rise as the stabilisation of the shoreface occurring in the previous period, changed to shoreface accretion. Consequently, the shoreline prograded more and more seaward, resulting in a shrinking of the channel network on the plain. This is demonstrated by the occurrence of intertidal mud deposits and peat accumulation in the extreme seaward part of the discussed area, and also by the presence of the peat bed beyond the present-day shoreline in some locations.

The prograding shoreline and shrinking channel network created favourable conditions on the plain for the freshwater swamps with peat accumulation to expand progressively more seaward and over the channel deposits. The long duration of the peat accumulation (about 3000 years) demonstrates that it could keep pace with the reduced rate of relative sea-level rise.

The vast freshwater swamp was out of the reach of almost all tidal activity as it was bordered by salt marshes, in turn bordered by mud flats and sand flats lying behind a coastal sand barrier (including the shoreface, sensu Roy et al, 1995; Roy and Boyd, 1996). Whether the coastal barrier emerged supratidally and/ or whether it was captured by a dune belt, could not be revealed from the existing data. The area might also have been an "open coast" tidal flat.

It has been demonstrated that freshwater swamps with peat accumulation can initiate short distances away from the sediment source. For this to occur, the area only has to be elevated above at least HAT, and be out of reach of the daily tidal flooding. Therefore, there is no need to invoke a continuous dune belt to explain the long and extensive peat formation, although this is always the case in the Belgian literature. Besides, if a dune belt did exist, it is impossible for it to be completely closed because then, sediment would no longer be supplied to the tidal flat in front of the freshwater swamp, changing the intertidal and supratidal flat into a lagoonal environment, which was not the case, except in De Moeren, an area located in the extreme west of the plain, and portaying a quite different evolution (Baeteman, 1985b). This contradicts Allemeersch (1991) who stated that the surface peat originated due to terrestrialisation occurring in a lagoon. In any event, a completely closed barrier would rapidly inundate and drown the peat because the drainage of the run-off would be hampered. 
The traces of tidal effect in the thick peat bed, even far landward, also suggest that channels remained open, although very much reduced, and mainly acting as drainage for the freshwater swamp. Local floodings of the latter, especially during different periods, also tend to denote a coastal barrier which was not completely closed and indicate that the main channels remained active.

\subsection{Period after ca. $4000 / 1500$ cal BP}

However, the local floodings herald the end of the progradation. Renewed peat growth after mudflat deposition and/or scour-and-fill of the channels indicate that initially, the tidal effect did not permanently change the environmental conditions of the freshwater swamp. Several similar situations of renewed peat growth have been encountered in the plain, most of them in the seaward portion and all during different periods ranging from about 4000 to 2500 cal BP, (e.g. Baeteman and Verbruggen, 1979; Baeteman and Van Strydonck, 1989; Baeteman et al., 1999). They suggest that the local floodings must be considered as precursors for the renewed landward migration of the tidal system and, moreover, that the latter happened in successive steps. (which however, must not be identified with the artificially established Dunkerque transgressions from the Belgian literature). The flooding was already well underway before the $2^{\text {nd }}$ and $4^{\text {th }}$ century $\mathrm{AD}$ (dates for the beginning of the first and second Dunkerque transgression, respectively). It is most likely that the shortlived renewed peat growth has been interpreted as "regression" separating the different Dunkerque transgressions by the Soil Survey in the 50's.

The origin of the renewed landward migration of the tidal system remains uncertain. RSL was still rising at the same average rate as in the previous period $(0.7 \mathrm{~m} /$ $\mathrm{ka})$. No evidence of a specific sudden increase has been found in the Belgian plain. As suggested by Beets et al. (1994), it is more likely that this is due to an imbalance of sediment budget to compensate for the relative sea-level rise. Due to the relative sea-level rise, even at a reduced rate, sediment was continuously needed. The sand sources were used to fill the palaeovalley and for the progradation of the shoreline, and thus became exhausted, so that new sources had to be found. This happened by eroding the previously deposited tidal-basin sediments, resulting in shoreface erosion. The erosion of the freshwater swamp enhanced and accelerated the mechanism. In association with the shoreface erosion, tidal inlet and channels migrated landward eroding the freshwater swamp, causing dewatering and compaction of it, which consequently lowered its surface (Baeteman and Denys, 1995).
The lowered surface of the marshes suddenly provided new accommodation space, forcing the channels to readjust by deep scouring because changes in tidal prism change the size and depth of the channel. The vertical erosion in turn enhanced the dewatering and compaction of the peat and, to some extent, the underlying deposits at low tide. The blocks of peat frequently found in the channel fills represent portions of collapsed channel walls which were most probably eroded during periods of storm-enhanced high tidal discharges. The ages of the top of the peat (Baeteman and Van Strydonck, 1989) suggest that this mechanism of landward channel network growth progressively proceeded more landward and ended at about 1500 cal BP. It resulted in the final fill of the area with mudflat deposits.

This mechanism contradicts the generally accepted view in the Belgian literature where compaction of the peat occurred after it was covered by mud (see Fig. 2). A sea-level rise was invoked for the deposition of the latter.

It is interesting to note that the tidal channels were again predominantly confined to the palaeovalleys (as illustrated for the landward part in Fig. 7). Only the Kemmelbeek escaped from later erosion. It should be mentioned that the original sand-filled tidal channels were not encountered in the bore holes covering the landward part of the palaeovalleys. It is most likely that the channels from this younger flooding reoccupied the same position. Such a situation could be observed in an open sand pit (Baeteman et al., 1999) but is impossible to detect from the bore holes. On the other hand, it is also possible that, in view of the distance from the main palaeovalley of the IJzer, sand never reached the landward part of the palaeovalleys and that the channels were only filled by mud.

Evidence for transgressive/regressive cycles (Dunkerque transgressions) as claimed in the Belgian literature, has not been found in the final sequence. This is not surprising, because recent research in Zeeland (where these cycles were initially established in the 50 's) firmly concludes that "sediments of the Duinkerke transgressive phases which were distinguished in the Duinkerke deposits have been inadequately or incorrectly dated because of improper use of archaeological evidence. Sedimentary facies of the Duinkerke deposits were incorrectly correlated with transgressive phases" (Vos and van Heeringen, 1997).

The silting up of the intertidal flat until supratidal level did not occur rapidly because a large (vertical and lateral) accommodation space had to be filled with a slow rate of relative sea-level rise. After the area changed 
into a salt marsh, it was reclaimed by man (from about 900 AD). The historically documented catastrophic floodings after $1000 \mathrm{AD}$ which were interpreted as the DIII phase of the Dunkerque transgression, occurred after the first reclamations and were mainly induced by man. Dikes were built perpendicular to the coast to prevent flooding from the channels. However, the embanking of salt marshes resulted in significantly less accommodation space with a consequently higher storm-surge level in the channels and gullies (Vos and van Heeringen, 1997). Moreover, the man-made drainage in the newly created polders caused subsidence of the surface. Such a situation gave rise to disastrous floodings when a dike burst. Because no new intertidal flats developed in the temporarily inundated areas, these floodings did not give rise to sediment deposition. This was not the case for the area around Oostende, where in 1584 and 1601 sea dikes were deliberately breached and the artificial inlets evolved to tidal channels deeply scouring the Holocene deposits (Baeteman, 1994). This human intervention drastically changed the landscape and resulted in "the polders of Oostende" after silting up and new reclamation.

Although catastrophic, the floodings were local and mainly localised along the channels (e.g. the river IJzer). Exactly when the river IJzer changed its position from the palaeovalley to its present-day location is not yet known. It is most likely that this occurred during such a catastrophic storm surge event.

\section{Final considerations}

The study of the Holocene sequence of a main palaeovalley and its tributaries has shown the complexity of the fill and facies distribution, laterally as well as vertically. The filling of the palaeovalley and the ultimate formation of the coastal plain were controlled by a decelerated relative sea-level rise, the palaeotopography and accommodation space, sediment supply and the configuration of the tidal flat, especially the distal and proximate position of the tidal channel in relation to a particular site. The position of the channels and creeks significantly determined the development of the different depositional environments during the fill. Changes in the rate of relative sea-level rise seems to be the only regional factor. All other controlling factors act locally and their identification requires an integration of local site-based studies in the context of the large-scale coastal behaviour of the entire tidal basin. It should be mentioned that possible crustal movements throughout the Holocene have not been considered and must still be investigated within this context.
The infill of the palaeovalleys did not occur continuously, nor gradually, but in successive steps. Changes between different depositional environments mutually, and between peat growth and tidal deposition occurred rapidly, and this also applies to the spatial distribution and the vertical succession. The changes and the succesive steps were not synchronous, not even over short distances, but depended on the local factors mentioned above. The facies sequence is much more sensitive to change in sediment supply than is generally assumed. The facies changes, in particular between mud and peat, is determined by sedimentological control under the conditions of a rapid relative sea-level rise and a landward migration of the channel network associated with a surpassing sediment supply. Periods of peat growth lasted longer and the lateral extension became more and more widespread as deceleration of the relative sea-level rise continued and the filling of the tidal basin proceeded, associated with the progradation of the shoreface.

Because of the irregular pattern of peat growth in time and space resulting from the combined action of the local factors which govern their formation, peat beds should no longer be used to differentiate stratigraphical units in the coastal sedimentary sequence.

The stratigraphical and sedimentological study, combined with age determinations, of the IJzer palaeovalley, representing the major part of the Holocene sequence of the western coastal plain showed that the stratigraphy differentiating Dunkerque and Calais as units on the basis of the presence of an intercalated peat bed, and overruling the research in the Belgian literature, should be abandoned in favour of lithological descriptions and age determinations accompanied by environmental interpretation revealing much more significant results.

\section{Acknowledgement}

I am grateful to Dirk Beets and Roland Gehlers for providing critical remarks and valuable suggestions about earlier drafts of this paper. Special mention to Dirk Beets for several fruitful discussions. Patrick Schotte digitised the top Tertiary data. This paper is a contribution to IGCP Project 437 "Coastal Environmental Change during Sea-level Highstands", and the INQUA Commission on Quaternary Shorelines. 


\section{References}

ALLEMEERSCH, L., 1991. Peat in the Belgian eastern coastal plain. In: GULLENTOPS, F. (ed.): Wetlands in Flanders. Aardkundige Mededelingen, 6, 1994, 1995, pp. 1-54.

ALLEN, G.P. and POSAMENTIER, H.W., 1993. Sequence stratigraphy and facies models of an incised valley fill: the Gironde Estuary, France. Journal of Sedimentary Petrology, 63, 3, 378-391.

ALLEN, J.R.L., 1995. Salt-marsh growth and fluctuating sea-level: implications of a simulation model for Flandrian coastal stratigraphy and peat-based sea-level curves. Sedimentary Geology, 100, 21-45.

ALLEN, J.R.L., 1997. Simulation models of salt-marsh morphodynamics: some implications for high-intertidal sediment couplets related to sea-level change. Sedimentary Geology, 113, 211-233.

AMERYCKX, J., 1959. De ontstaansgeschiedenis van de zeepolders. Biekorf, 60, pp.1-26.

AMERYCKX, J. and VERHULST, A., 1958. Enkele historisch-geografische problemen in verband met de oudste geschiedenis van de Vlaamse Kustvlakte. Handelingen der Maatschappij voor Geschiedenis en Oudheidkunde te Gent, 12, 3-26.

BAETEMAN, C., 1978a. New evidence on the marine Holocene in the western Belgian coastal plain. Bulletin van de Belgische Vereniging voor Geologie, 87, 49-54.

BAETEMAN, C., 1978b. L'extension de la Formation d'Herzeele en Belgique. Bulletin de l'Association française pour l'étude du Quaternaire, 15, 54-55-56, 141-144.

BAETEMAN, C., 1981a. De Holocene ontwikkeling van de Westelijke kustvlakte (België). Unpublished PhD Thesis, Vrije Universiteit Brussel, 297p.

BAETEMAN, C., 1981b. An alternative classification and profile type map applied to the Holocene deposits of the Belgian coastal plain. Bulletin van de Belgische Vereniging voor Geologie, 90, 4, 257-280.

BAETEMAN, C., 1983. De Holocene sedimenten van de westelijke kustvlakte: een analyse van de Belgische litteratuur. Professional Paper, Belgian Geological Survey, 9/204, 45p.

BAETEMAN, C., 1985a. Development and evolution of sedimentary environments during the Holocene in the western coastal plain of Belgium. Eiszeitalter und Gegenwart, 35, 23-32.

BAETEMAN, C., 1985b. The origin of De Moeren. In: VAN MOLLE, M. (ed.), Recent trends in physical geography in Belgium. Study series of the Vrije Universiteit Brussel, New Series, 20, pp. 31-43.

BAETEMAN, C., 1987. Mapping a coastal plain. Problems concerning mapping units. Geobound, 1, 1, 3-9.

BAETEMAN, C., 1991. Chronology of the coastal plain development during the Holocene in West Belgium. Quaternaire, 2 (3/4), 116-125.

BAETEMAN, C., 1993. The western Coastal Plain of Belgium. In: BAETEMAN, C. and de GANS, W. (eds), Quaternary Shorelines in Belgium and The Netherlands. Excursion Guide of the 1993 Fieldmeeting of the INQUA Subcommission of Shorelines of Northwestern Europe, pp.1-24 and pp.43-55.

BAETEMAN, C., 1994. The Late Holocene sedimentary environment of the archaeological site "het Mijnplein", Oostende. Archeologie in Vlaanderen, IV, 199-201.

BAETEMAN, C., BEETS, D.J. and VAN STRYDONCK, M., (1999). Tidal crevasse splays as the cause of rapid changes in the rate of aggradation in the Holocene tidal deposits of the Belgian coastal plain. Quaternary International, 56, 3-13.

BAETEMAN, C. and DENYS, L., 1995. Western Coastal Plain of Belgium. In: SCHIRMER, W. (ed.): Quaternary field trips in Central Europe, Volume 2: North Sea Coasts. München: Verlag Dr. Friedrich Pfeil, pp. 1010-1014.

BAETEMAN, C. and DENYS, L., 1997. Holocene shoreline and sea-level data from the Belgian coast. In: ERONEN, M., FRENZEL, B., PIRAZZOLI, P. and WEISS, M. (eds): Sea-level changes during Holocene times. Palaeoclimate Research, 21, ESF Special Issue 14, 49-74 (in press).

BAETEMAN, C., CLEVERINGA, P. and VERBRUGGEN, C., 1981. Het paleomilieu rond het Romeins zoutwinningssite van Leffinge. Professional Paper, Geological Survey of Belgium, 7/186, 33p.

BAETEMAN, C. and VAN STRYDONCK, M., 1989. Radiocarbon dates on peat from the Holocene coastal deposits in West Belgium. In: BAETEMAN, C. (ed.): Quaternary sea-level investigations from Belgium. Professional Paper, Geological Survey of Belgium, 6/ 241, 59-91. 
BAETEMAN, C. and VERBRUGGEN, C., 1979. A new approach to the evolution of the so-called surface peat in the Western Coastal Plain of Belgium. Professional Paper, Geological Survey of Belgium, 11/167, $32 \mathrm{p}$.

BEETS, D.J., van der SPEK, A.J.F. and van der VALK, L., 1994. Holocene ontwikkeling van de Nederlandse kust. RGD rapport 40.016 - Project Kustgenese, 53p.

CORNET, J., 1927. Leçon de Géologie. Bruxelles: Edition M. Lamertin, 674p.

DALRYMPLE, R.W., ZAITLIN, B.A. and BOYD, R., 1992. Estuarine facies models: conceptual basis and stratigraphic implications. Journal of Sedimentary Petrology, 62, 1130-1146.

DE CEUNYNCK, R., 1985. The evolution of the coastal dunes in the western Belgian coastal plain. Eiszeitalter und Gegenwart, 35, 33-41.

DE MOOR, G. and MOSTAERT, F., 1993. Eemian and Holocene evolution of the eastern part of the Belgian coastal plain. In: BAETEMAN, C. and de GANS, W. (eds), Quaternary Shorelines in Belgium and The Netherlands. Excursion Guide of the 1993 Fieldmeeting of the INQUA Subcommission of Shorelines of Northwestern Europe, pp. 94-108.

DE MOOR, G. and PISSART, A., 1992. Het reliëf. In: Geografie van België. Brussel: Nationaal Comité voor Geografie, Gemeentekrediet, pp. 129-215.

DENYS, L., 1985. Diatom analysis of an AtlanticSubboreal core from Slijpe (western Belgian coastal plain). Rev. Palaeobot. Palynol., 46, 33-53.

DENYS, L., 1989. Observations on the transition from Calais deposits to surface peat in the western Belgian coastal plain - results of a paleoenvironmental diatom study. In: BAETEMAN, C. (ed.): Quaternary sea-level investigations from Belgium. Professional Paper, Geological Survey of Belgium, 6/241, 20-43.

DENYS, L., 1993a. Paleoecologisch diatomeeënonderzoek van de Holocene afzettingen in de westelijke Belgische kustvlakte. Unpublished PhD Thesis, Universitaire Instelling Antwerpen.

DENYS, L., 1993b. The diatom record of Holocene deposits near Oostkerke and the development of the Avekapelle gully. In: BAETEMAN, C. and de GANS, W. (eds), Quaternary Shorelines in Belgium and The Netherlands. Excursion Guide of the 1993 Fieldmeeting of the INQUA Subcommission of Shorelines of Northwestern Europe, pp. 25-42.
DENYS, L., 1993c. Holocene valley fills at the southern limit of the western Belgian coastal plain - general palaeoecological outline. In: BAETEMAN, C. and de GANS, W. (eds), Quaternary Shorelines in Belgium and The Netherlands. Excursion Guide of the 1993 Fieldmeeting of the INQUA Subcommission of Shorelines of Northwestern Europe, pp. 56-73.

DENYS, L., 1999. A diatom and radiocarbon perspective of the palaeoenvironmental history and stratigraphy of Holocene deposits between Oostende and Nieuwpoort (western coastal plain, Belgium). Geologica Belgica, 2, 111-140.

DENYS, L. and BAETEMAN, C., 1995. Holocene evolution of relative sea-level and local mean high water spring tides in Belgium - a first assessment. In: VAN DE PLASSCHE, O., CHRZASTOWSKI, M.J., ORFORD, J.D., HINTON, A. and LONG A.J. (eds): Coastal evolution in the Quaternary, Marine Geology, 124, 1-19.

DUBOIS, G., 1924. Recherches sur les terrains quaternaires de Nord de la France. Mémoires de la Société Géologique du Nord , 8, 355p.

FOREST, L. and VAN STRYDONCK, M., 1993. The installation of a liquid scintillator and the construction of a benzene synthesis unit at the radiocarbon dating laboratory. Bulletin KIK-IRPA, 25, 235-245.

GULLENTOPS, F. and BROOTHAERS, L., 1996. Overzicht van de geologie van Vlaanderen. In: GULLENTOPS, F. and WOUTERS, L. (eds), Delfstoffen in Vlaanderen. Lier: Drukkerij Antilope, pp. 127.

HOUTHUYS, R., DE MOOR, G. and SOMME, J., 1993. The shaping of the French-Belgian North Sea Coast throughout recent geology and history. In: HILLEN, R. and VERHAGEN, H.J. (eds), Coastlines of the Southern North Sea. New York: American Society of Civil Engineers, pp. 27-40.

KÖHN, W., 1989. The Holocene transgression of the North Sea as exemplified by the southern Jade bay and the Belgian coastline. Essener Geogr. Arbeiten, 17, 109-152.

LOUWYE, S. and DECLERCQ, E., 1998. Relative water level change in the intracoastal zone of Belgium and Northern France over the last 2500 years. Boreas, $27,162-177$.

MARECHAL, R., 1953. Ontstaan en morfologie van de Golf van Lo. Natuur Wetenschappelijk Tijdschrift, $35,159-166$. 
MARECHAL, R., 1992a. Kwartairgeologie, Lithologie van de oppervlakkige lagen. Tweede atlas van België, Blad II. 3, 25p.

MARECHAL, R. 1992b. De geologische structuur. In: Geografie van België. Brussel: Nationaal Comité voor Geografie, Gemeentekrediet, pp. 37-86.

MOORMANN, R., 1951. De bodemgesteldheid van het Oudland van Veurne Ambacht. Natuur Wetenschappelijk Tijdschrift, 33, 3-124.

MOORMANN, F.R. and AMERYCKX, J.B., 1950. De bodemgesteldheid van de Zeepolders. I.W.O.N.L. Verslagen over Navorsingen, 4, 37-60.

MOSTAERT, F., 1985. Bijdrage tot de kennis van de Kwartairgeologie van de oostelijke kustvlakte op basis van sedimentologisch en lithostratigrafisch onderzoek. Unpublished $\mathrm{PhD}$ Thesis, Universiteit Gent.

MOSTAERT, F., 1989. Holocene sea-level indicators in the eastern part of the Belgian coastal plain. In: BAETEMAN, C. (ed.): Quaternary sea-level investigations from Belgium. Professional Paper, Geological Survey of Belgium, 6/241, 44-58.

OOST, A.P. and DE BOER, P.L., 1994. Sedimentology and development of barrier islands, ebb-tidal deltas, inlets and backbarrier areas of the Dutch Wadden Sea. Senckenbergiana Maritima, 24, 65-115.

PONNIAH, J., 1977. Pollenanalytic studies of the Holsteinian in the Izenberge area, Belgium. Unpublished thesis, IFAQ, VUB, Brussel.

ROY, P.S. and BOYD, R., 1996. Quaternary Geology of a Tectonically Stable, Wave-Dominated, SedimentDeficient Margin, Southeast Australia. IGCP Project \# 367, Field Guide to the Central New South Wales Coast. November 1996. New South Wales Geological Survey, Sydney, 174 p.

ROY, P.S., COWELL, P.J., FERLAND, M.A. and THOM, B.G., 1995. Wave-dominated coasts. In: CARTER, R.W.G. and WOODROFFE, C.D. (eds), Coastal Evolution: Late Quaternary shoreline morphodynamics. Cambridge: University Press, pp. 121-186.

SHENNAN, I, 1986. Flandrian sea-level changes in the Fenland. II: Tendencies of sea-level movement, altitudinal changes, and local and regional factors. Journal of Quaternary Science, 1, 2, 155-179.

SHENNAN, I., TOOLEY, M.J., DAVIS, M.J. and HAGGART, B.A., 1983. Analysis and interpretation of Holocene sea-level data. Nature, 302, 404-406.
STOCKMANS, F. and VANHOORNE, R, 1954. Etude botanique du gisement de tourbe de la région de Pervijze (Plain maritime belge). Verhandelingen Kon. Belg. Inst. Natuurwetenschappen, 130, 144p.

STONE, P.A. and GLEASON, P.J., 1981. Environmental and paleoenvironmental significance of organic sediments (peats) in Southeastern United States. In : COLQUHOUN, D.J. (ed.): Variations in sea-level on the South Carolina Coastal Plain. University of South Carolina, pp. 121-133.

STREIF, H., 1978. A new method for the representation of sedimentary sequences in coastal regions. Proceedings 16th Coastal Engineering Conference, ASCE, Hamburg, pp. 1245-1256.

STUIVER, M. and BRAZIUNAS, T.F., 1993. Modeling atmospheric ${ }^{14} \mathrm{C}$ influences and ${ }^{14} \mathrm{C}$ ages of marine samples to 10.000 BC. Radiocarbon, 35, 137-189.

STUIVER, M. and REIMER, P.J., 1993. Extended ${ }^{14} \mathrm{C}$ data base and revised CALIB $3.0{ }^{14} \mathrm{C}$ age calibration. Radiocarbon, 35, 215-230.

STUIVER, M. and PEARSON, G.W., 1993. High-precision calibration of the radiocarbon time scale, AD 1950-500 BC and 2500-6000 BC. Radiocarbon, 35, $1-23$.

TAVERNIER, R., 1938. De geologische ontwikkeling van de Vlaamse Kust. Wetenschap in Vlaanderen, 4, 1-2, 19p.

TAVERNIER, R., 1943. De Kwartaire Afzettingen van België. Natuur Wetenschappelijk Tijdschrift, 25, 121137.

TAVERNIER, R., 1946. L'évolution de Bas Escaut au Pleistocène supérieure. Bulletin de la Société belge de Géologie, 55, 106-125.

TAVERNIER, R., 1947. L'évolution de la plaine maritime belge. Bulletin de la Société belge de Géologie, $56,332-343$..

TAVERNIER, R., 1948. De jongste geologische geschiedenis der Vlaamse Kustvlakte. Handelingen der Maatschappij voor Geschiedenis en Oudheidkunde te Gent, 3, 2, 107-115.

THOEN, H., 1978. De Belgische kustvlakte in de Romeinse tijd. Verhandelingen Koninklijke Academie van België, Klasse der Letteren, 40, pp. 1-225. 
THOEN, H. (ed.), 1987. De Romeinen langs de Vlaamse kust. Brussel: Gemeentekrediet, 181p.

VAN CAUWENBERGHE, C., 1993. Overzicht van de tijwaarnemingen langs de Belgische kust - Periode 19811990. Infrastructuur in het Leefmilieu, 6, 421-440.

VAN DEN BERG, J.H., 1982. Migration of large-scale bedforms and preservation of crossbedded sets in highly accretional parts of tidal channels in the Oosterschelde, SW Netherlands. Geologie en Mijnbouw, 61, 3, 253-263.

VAN der SPEK, A.J.F. and BEETS D.J., 1992. MidHolocene evolution of a tidal basin in the western Netherlands: a model for future changes under conditions of accelerated sea-level rise? Sedimentary Geology, 80, 185-197.

VAN STRYDONCK, M., LANDRIE, M., HENDRIX, V. VAN DER BORG, K., DE JONG, A.F.M., ALDERIESTEN, C. and KEPPENS, E., 1998. Royal Institute for Cultural Heritage - Radiocarbon dates XVI. Koninklijk Instituut voor het Kunstpatrimonium, Brussel, 59 p.

VAN STRYDONCK, M. and VAN der BORG, K., 1991. The construction of a preparation line for AMS- targets at the Royal Institute for Cultural Heritage, Brussels. Bulletin KIK-IRPA, 23, 228-234.

VOS, P.C. and van HEERINGEN, R.M., 1997. Holocene geology and occupation history of the Province of Zeeland. In: FISCHER, M.M. (ed.), Holocene evolution of Zeeland (SW Netherlands). Mededelingen Nederlands Instituut voor Toegepaste Geowetenschappen TNO, 59, pp. 5-109.

ZAITLIN, B.A., DALRYMPLE, R.W. and BOYD, R., 1994. The stratigraphic organisation of incised-valley systems associated with relative sea-level change. In: DALRYMPLE, R.W., BOYD, R. and ZAITLIN, B.A. (eds): Incised-valley systems: origin and sedimentary sequences. Society for Sedimentary Geology, Special Publication, 51, 45-60.

ZAGWIJN, W.H. and VAN STAALDUINEN, C.J., 1975. Toelichting bij de geologische overzichtskaarten van Nederland. Rijks geologische Dienst, Haarlem, $134 \mathrm{p}$.

Manuscript received on 16.09.1997 and accepted for publication on 28.06.1999. 